\title{
PFI 事業とモラルハザード
}

\author{
石磊 $^{1} \cdot$ 大西正光 $^{2} \cdot$ 小林潔司 ${ }^{3}$ \\ 1学生会員 京都大学大学院博士後期課程 都市社会工学専攻 ( 7 615-8540 京都市西京区京都大学桂) \\ E-mail:shi@stone.mbox.media.kyoto-u.ac.jp \\ 2 正会員 京都大学大学院助手 工学研究科都市社会工学専攻 ( $\overline{7}$ 615-8540 京都市西京区京都大学桂) \\ E-mail: masa@psa.mbox.media.kyoto-u.ac.jp \\ 3 フェロー会員 京都大学経営管理大学院教授 経営管理講座 ( $\bar{T}$ 606-8501 京都市左京区吉田本町) \\ E-mail:kkoba@psa.mbox.media.kyoto-u.ac.jp
}

\begin{abstract}
本研究ではPFI(Private Financial Initiative) 事業におけるモラルハザードを克服するための保証金・モニタ リングについて考察する. その際, モラルハザードのタイプとして, 技術的・財務的モラルハザードが存在す ることを指摘する．事業権契約に保証金を導入することにより，技術的・財務的モラルハザードを抑制できる が，保証金の機会費用が発生する。一方，金融機関によるモニタリングにより，財務的モラルハザードを抑制 することが可能である。しかし，モニタリングのみでは技術的モラルハザードを抑制できない．PFI事業によ るモラルハザードを効率的に抑制するためには，モニタリングにより財務的モラルハザードを抑制しつつ，技 術的モラルハザードを抑制するための保証金額を低減させるような方策が望ましいことを示す。
\end{abstract}

Key Words : PFI project, moral hazard, incomplete contract, liquidation, monitoring, guarantee

\section{1.はじめに}

PFI(Private Financial Initiative) 事業に参画する主 なプレイヤーとして, SPC(Special Purpose Company), 金融機関及び公共主体を考えるＰFI事業を実施する ために, 公共主体はSPC と事業権契約を締結する。事 業権契約においては，SPCが契約期間中に提供すべき サービス水準とそれに対する対価が記述される。一方， SPC と金融機関との間に負債契約が締結され，初期融資 額と契約期間中における返済スケジュールが決定する.

負債契約は有限責任であり，SPCは事業破綻時，あ るいは事業権契約解除時に負債返済の義務が免除され る.さらに，負債契約は将来生起する事象のすべてに 対応できず，不完備契約とならざるを得ない。このよ うな負債契約の有限責任と不完備性に起因して, PFI 事業ではSPCによるモラルハザードが発生する可能性 を否定できない，さらに，事業破綻時に公共主体が事 業を買収する場合，SPC と金融機関の双方にモラルハ ザードが発生する可能性がある，本研究では，モラル 八ザードを抑制する方策として公共主体による保証金 の徵収，金融機関によるモニタリング制度に着目する.

一般に，SPCによるモラルハザードには，2．（3） で議論するような技術的モラルハザードと財務的モラ ルハザードが存在する．公共主体が事業権契約の段階 でSPCから徴収する保証金制度は，技術的・財務的モ ラルハザードの抑制に有効である。しかし，保証金が 高額になると保証金の機会費用が発生し，財務的効率
性が保証できない，一方，モニタリングは財務的モラ ルハザードの抑制に有効であるが，す心゙てのモラルハ ザードを抑制できないという限界がある。本研究では, PFI事業におけるモラルハザードを効率的に抑制する ためには，金融機関のモニタリングにより財務的モラ ルハザードを抑制し，公共主体が徵収する保証金の金 額を削減する努力が必要であることを指摘する.

本研究では, 不完備契約ゲーム理論を用いて, PFI 事業でモラルハザードが発生するメカニズムを表現し, 保証金とモニタリングが，モラルハザードを抑制する 効果について分析する. 以下，2. では，本研究の基 本的な考え方を説明する．3．では，PFI事業契約を基 本モデルとして定式化する．4，では競争入札モデル を定式化し，モラルハザードが発生するメカニズムを 分析する．5．では保証金，6。ではモニタリングを 導入した不完備契約今゙ームをモデル化し，これらの方 策がモラルハザードを抑制する効果について分析する.

\section{2. 本研究の基本的な考え方}

\section{（1）従来の研究概要}

PFI事業において, 公共主体とSPC の間の事業権契 約，金融機関と SPCの間の負債契約ともに，契約内容 に曖昧性が含まれる不完備契約1)-7) とならざるを得な い. 不完備契約理論に基づいて, 民営化, PPP (Public Private Partnership) の効率性 8 - -10) やPFI 事業の効率 性 $\left.{ }^{11)}-14\right)$ に関する研究の蓄積がある. 中でも, 三井12) 
は，民営化による内部情報の遮断と負債による規律づ け機能15),16)を通じてソフトな予算問題17)を防ぐこと が可能であることを明らかにした．また，筆者らも，将 来の外部経済便益に関寸る不確実性や事業の効率的な 清算リスクの視点から, PFI事業における保証金・補助 金が果たす役割について分析している13),14)。中でも， 石等 ${ }^{14)}$ は，資産代替や非効率な事業清算が生起しうる ような非効率な事業権契約のスクリーニング問題を分 析している。その結果, 保証金システムにより, SPC による資産代替行動を抑制し，非効率な事業清算を抑 止できることを示している．しかし，そこではSPCに よるモラルハザードの問題を取り扱っていない.

モラルハザード問題に関しては，すでに膨大な研究の 蓄積があり, 標準的なプロトタイプモデルが提案されて いる1),2),20)。モラルハザードは監査者（公共主体・金 融機関）と被監查者 $(\mathrm{SPC})$ の間における情報の非対称 性に起因して生じる.このため, SPCのモラルハザー ドを直接的な方法で規制することは困難であり，SPC がモラルハザードを抑止するようなインセンティブを 賦与することが必要となる，その結果，情報の非対称 性に起因して, SPCの行動を規律づけするためのエー ジェンシー費用1)が発生する．2（2）で言及するよ うに，SPCによる資産代替とモラルハザードは，とも に事業権契約・負債契約の不完備性，SPCの有限責任 性18，19) に起因して生じる機会主義的行動である.さら に，4.(4) で考察するように，金融機関にもモラルハ ザードが生起する可能性がある．PFI事業においては， 契約段階におけるスクリーニング機能と, 事業実施段 階におけるインセンティブ機能を組み合わせ，エージェ ンシ費用を可能な限り縮減することが課題となる。こ のようなPFI事業のモラルハザードに関しては十分に 研究が蓄積されていない. 本研究では石等の不完備契 約モデル14)を拡張し, PFI事業におけるモラルハザー ドを抑止する方策の効果を分析することを目的とする.

\section{（2）モラルハザードと資産代替}

負債契約は有限責任であり，SPCは事業破綻時，あ るいは事業権契約解除時に負債返済の義務が免除され る.さらに, 負債契約は将来生起する事象のすべてに 対応できず，不完備契約とならざるを得ない。このよう な負債契約の有限責任と不完備性に起因して，PFI事業 ではSPCによる資産代替（債務契約の有限責任に伴い， 危険プロジェクトが選択される現象6) や やモラルハザー ドが発生する可能性がある。資産代替とモラルハザー ドはSPCによる機会主義的な行動であり，いずれも事 業の効率性を低下させる原因となる．表一 1 に資産代 替とモラルハザードにおける SPC の費用構造，利潤構 造の相違点を例示している. 本事例で $C_{0}<C_{1}<C_{2}$,
表ー 1 資産代替とモラルハザード

\begin{tabular}{c|cc|cc}
\hline \multirow{2}{*}{ 状態 } & \multicolumn{5}{|c}{ 費用構造 } \\
\cline { 2 - 5 } & \multicolumn{2}{|c}{ 資 産 代 替 } & \multicolumn{2}{c}{ モラルハザード } \\
\hline$\omega_{1}$ & $e_{d}$ & $e_{s}$ & $e_{L}$ & $e_{H}$ \\
$\omega_{2}$ & $C_{0}$ & $C_{1}$ & $C_{1}$ & $C_{1}$ \\
$\omega_{3}$ & $C_{2}$ & $C_{1}$ & $C_{2}$ & $C_{1}$ \\
\hline & $C_{2}$ & $C_{2}$ & $C_{2}$ & $C_{2}$ \\
\cline { 2 - 5 } & \multicolumn{4}{|c}{ 利潤構造 } \\
\cline { 2 - 5 } 状態 & 資 産 代 替 & \multicolumn{2}{c}{ モラルハザード } \\
\hline$\omega_{1}$ & $e_{d}$ & $e_{s}$ & $e_{L}$ & $e_{H}$ \\
$\omega_{2}$ & $R-C_{0}$ & $R-C_{1}$ & $R-C_{1}+B$ & $R-C_{1}$ \\
$\omega_{3}$ & 0 & $R-C_{1}$ & $B$ & $R-C_{1}$ \\
\hline
\end{tabular}

注） $\mathrm{SPC}$ が $e_{d}, e_{L}$ を採用することにより $C_{2}$ が発生する（事 業が破綻する）確率が高くなる。 る. 事業が破綻しない確率 $p_{s}=p_{H}=p\left(\omega_{1}\right)+p\left(\omega_{2}\right), p_{d}=$ $p_{L}=p\left(\omega_{1}\right)$ と定義すれば $p_{s}=p_{H}>p_{L}=p_{d}$ が成立する. $e_{d}, e_{s}$ は危険なプロジェクト, 安全なプロジェクトを表す. $e_{L}, e_{H}$ は低い努力水準, 高い努力水準を表す.

$R<C_{2}$ が成立すると考えよう. 費用 $C_{2}$ が発生した場合, $R<C_{2}$ となるため, 事業が破綻する。しかし，SPC は 有限責任であり， $R-C_{2}<0$ の支払い義務はない. 事業 破綻時には利潤は 0 となる。資産代替はSPCが危険な プロジェクト $e_{d}$ を採用することにより高い利潤 $R-C_{0}$ を獲得しようとする行動である。一方，モラルハザード の場合にも, 費用 $C_{2}$ が発生した場合に事業が破綻する. しかし，努力水準 $e_{L}$ を採用した場合，事業の破綻の有 無に関わらず SPC は私的便益 $B$ を追加的に獲得する.

資産代替では事業破綻後の社会的に非効率な事業清 算と，事前のSPCの行動の規律づけが問題となる。す なわち，事業破綻後の事業の継続を担保するような制度 を設ければ，逆にSPCがリスクの高いプロジェクトを 採択寸る可能性がある。筆者らは, SPC の資産代替行 動をとりあげ，公共主体が事業権締結時にSPCから自 己資金による保証金を徵収することにより資産代替行 動を抑制できることを明らかにした ${ }^{14)}$ ，すなわち，事 業締結時に事業の非効率性が生起するような契約を事 前に排除するようなスクリーニングを実施することに より資産代替の問題は回避できる。一方，モラルハザー ドは事業の破綻前の段階で発生する，表－1に示すよ うに，仮に事業が破綻しても，その時点でSPCはすで に私的便益を獲得しており，正の利潤を獲得し事業を 清算することが可能である．したがって，事業を効率 的に継続する方策とモラルハザードの誘因の間には直 接の関係はない。このようなモラルハザードを抑制す るためには，モラルハザードの原因となる私的便益 $B$ の発生を抑止することが必要となる，次節で言及する ように，監查機関が私的便益 $B$ を観察可能，立証可能 な場合もあるが，立証不可能である場合が少なくない． 私的便益 $B$ が私的情報である場合, この点がモラルハ ザードを抑止する方策を設計することを困難にしてい 
る、モラルハザードを抑止するためには，契約締結の 段階でモラルハザードが発生するような契約を事前に 排除するスクリーニング機能と, 事業実施段階でSPC がモラルハザードを引き起こす誘因を除去するインセ ンティブ機能を設計することが必要となる.

\section{（3）財務的・技術的モラルハザード}

本研究ではSPCが負債契約で調達した資金を, 本来 の運営資金として用いず，私的便益獲得のため用いる 行動をモラルハザードと呼ぶ.さらに，SPCのモラル 八ザードのタイプを財務的モラルハザードと技術的モ ラルハザードに大別しよう，前者は，事業資金の目的外 使用等が該当し，モラルハザードの有無が会計情報等 を通じて立証可能なモラルハザードである。モラルハ ザードが発見された場合, 金融機関は返済請求等を通 じてSPCが享受した私的便益を回収できると考えよう. したがって，金融機関がSPC の行動を常時モニタリン グすることにより，SPCが獲得する私的便益を0にす ることが可能である。しかし，金融機関がモニタリン グを実施するためには，モニタリング費用が発生する. 金融機関がモニタリングをしない場合には，私的便益 を0にできない，一方，技術的モラルハザードは，SPC が専門的・技術的な知識や情報を利用して私的便益を獲 得する行動である．技術的モラルハザードは, 観察可 能ではあるが，立証不可能であると考えよう。したがっ て，金融機関によるモニタリングのみでは，技術的モ ラルハザードを抑制できないと考える. 技術的モラル 八ザードを抑制するためには，SPCがモラルハザード を引き起こす誘因を除去することが必要となる.

本研究では, SPCのモラルハザード行動を抑制する ための方策として，SPCに一定額の準レントを与える 最低価格入札制度, 公共主体が事業権締結時に預かり 金を徵収する保証金制度をとりあげる。これらの制度 は，いずれも財務的・技術的モラルハザードを抑制す ることが可能である. しかし, 最低価格入札制度では, $\mathrm{SPC}$ に準レントを供与寸るため, 財務的効率性を達成 できない。保証金制度では，保証金の徴収に際し，機 会費用やリスク費用が発生するため社会的効率性が低 下寸るという問題がある. 本研究では, SPCのモラル 八ザードを効率的に抑制するためには，これらの方策 を組み合わせ，エージェンシー費用を縮減する必要が あることを明らかにする。

\section{（4）本研究におけるPFI事業スキーム}

PFI 事業が SPC と公共主体の間で結ばれる事業権契 約と, SPC と金融機関の間における負債契約で構成さ れると考える. 3.ではSPCの行動に対してモニタリ ングが実施されない場合を想定し，公共主体，金融機

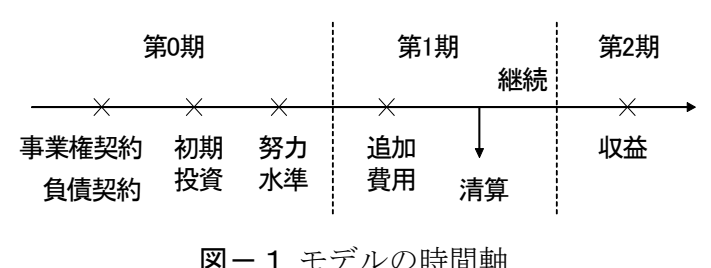

関，SPCによる意思決定，交渉過程を基本ゲームとし てモデル化する．また，4，では，PFI事業のサービス 対価が競争入札により決定される過程をモデル化する. 本研究では, BOT (Build-Operate-Transfer)方式によ るPFI事業の展開を想定し, PFI事業のプロジェクト ライフを，1) 契約が締結され，施設が建設される第 0 期，2）施設の運営が実施される第 1 期，3）PFI事業 が終了する第 2 期に分割する. 基本ゲームにおける事業 権契約と負債契約の展開を図ー 1 に整理している。す なわち, 第 0 期に, 競争入札により, ある特定の $\mathrm{SPC}$ が選択され，公共主体と SPC の間に事業権契約が，金 融機関とSPC の間に負債契約が締結され, 第 0 期に施 設の建設が終了する.さらに, SPCが努力水準を決定 する. 第 1 期の施設の運営期に, 事業が破綻するリスク が存在する. 第 0 期に SPCが高い努力水準を選択した 場合, 第 1 期の破綻リスクは小さくなる. 一方, 第 0 期 にSPCが低い努力水準を選択した場合, 事業が破綻す るリスクが大きくなる。事業が破綻した場合, 公共主 体が事業の解除権を行使する。さらに，金融機関は介 入権を有しており，金融機関が事業を継続するかどう かを決定する. 第 1 期に事業が継続された場合, 第 2 期 に公共主体が SPC にサービス対価を支払う．SPC は金 融機関に負債を返済し, PFI事業が終了する.

\section{3. 基本ゲーム}

\section{（1）モデル化の前提条件}

本研究では, SPCが金融機関との負債契約により資 金調達する場合を考える，基本ゲームでは，金融機関に よるモニタリングも実施されない. 金融機関によるモニ タリングの問題は，6．で議論する．PFI事業の時間的 な展開を図ー 1 に示す 3 期間モデルで表現する. 第 0 期 にSPC は公共主体と PFI 事業権契約を締結する。つい で, 金融機関との間で負債契約を締結する. 負債契約に よる融資額 $I$ は事業費用に一致し, 建設費用 $V$ と運営費 用 $B$ で構成される. 寸なわち, $I=B+V$ が成立する. $\mathrm{SPC}$ は初期投資 $V$ を支出し, 施設を建設する. 施設建 設段階で建設費用 $V$ は建設業者に支払われる。ささら, $\mathrm{SPC}$ は, 努力水準 $e \in\left\{e_{H}, e_{L}\right\}$ を選択寸る. 努力水準 
$e=e_{i}(i=H, L)$ を採用した場合, 努力費用 $F(e)$ は

$$
F(e)= \begin{cases}B & \left(e=e_{H} \text { の時 }\right) \\ 0 & \left(e=e_{L} \text { の時 }\right)\end{cases}
$$

が支出される. 第 0 期に, $\mathrm{SPC}$ は努力水準 $e_{i}(i=H, L)$ を決定し，努力費用は第 0 期中に支出される。 SPCが $e_{L}$ を選択した場合（モラルハザードが生じた場合）, 運 営費用 $B$ は，第 0 期に私的便益のために利用される．基 本モデルでは, 努力水準は観察可能であるが, 立証不可 能であると仮定する。また，私的便益に関する情報は 公共主体，金融機関，SPCの間で共有情報である。本 研究では，分析の焦点を負債契約に絞るため, SPCが 自己資本金を持たず，外部資金を全部負債により調達 すると仮定する. 負債契約には，初期融資額 $I$ と返済金 Dが記述される。返済金には元本だけではなく, 事業 破綻による期待損失（以下，クレジットリスクプレミ

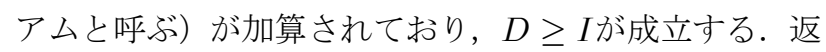
済金はすべて第 2 期に返済される。記述の簡単化のため に, 金額表示される変数はすべて第 0 期の現在価值で表 現されている.

第1期は，PFI事業の運営期である.PFI事業には経 営破綻リスクが存在する. 事業が破綻した場合, 事業 を継続するために追加融資 $C$ が必要となる. 破綻した 事業の継続費用 $C$ は事業費用 $I$ よりも小さく,

$$
I \geq C
$$

が成立すると考える. 追加融資を受けない場合, PFI事 業は清算される. SPCが第 0 期に努力水準 $e_{H}$ を選択し た場合は, 確率 $1-p_{H}$ で事業が破綻するリスクが存在 する. 一方, SPCが努力水準 $e_{L}$ を選択した場合, 事業 が破綻するリスクは $1-p_{L}$ と表される。ただし,

$$
p_{H}>p_{L}
$$

が成立する。

第 2 期に PFI 事業は完了する. 第 2 期は論理的に設け た期間であり，事業権契約，負債契約が清算される。事 業が第 2 期まで継続されれば，公共主体はSPCにサー ビス対価 $R$ を支払い，事業権契約が清算される。も ろん, 公共主体が SPCに中間支払いを行ってもいいが, 議論を単純にするために, 第 2 期にサービス対価 $R$ が支 払われると考える. サービス対価 $R$ に関して,

$$
I+C>R \geq I
$$

が成立する. $R \geq I+C$ が成立する場合, $\mathrm{SPC}$ が努力 水準にかかわらず非負の利潤を獲得する。このことは, 公共主体から SPCに対して所得移転が行われているこ とに他ならない. 公共主体は事業のVFMを最大にする ことを目的としており， $I+C>R$ が成立する。一方， $R \geq I$ は, サービス対価が事業費用を十分にファイナン スできることを意味する.
第 1 期に事業が破綻した場合，公共主体は既存 SPC との事業権契約を解除することを宣言する．金融機関 が公共主体の解除権行使を受諾すれば，事業が清算され る. 公共主体は金融機関に買取り価格 $A$ を支払い，事 業資産を買い取る。買取り価格 $A$ に関しては

$$
0 \leq A \leq I
$$

が成立する，すなわち，SPCが破綻する場合，買取り 価格は初期融資額 $I$ より小さい.さらに, 公共主体は事 業継続のための追加費用 $C$ を支出する. 公共主体は新 しい事業者を選択する。もしくは，直轄で事業を運営す る. 現実には, 公共主体と既存の SPCとの間に, 取引 特殊的な関係が成立しており, 既存 SPCが新たな事業 者として選ばれる可能性が高い。本研究では既存事業 者，あるいは新規事業者により事業を継続しても，第 2 期におけるプロジェクト費用は同一であると考えよう. この時，公共主体にとって，既存事業者による事業継 続と新規事業者による事業継続は無差別となる。そこ で，公共主体による事業権解除後においても，既存の $\mathrm{SPC}$ により事業が継続されると考える.

一方，金融機関は公共主体による事業権解除を拒否 することもできる．この場合，金融機関は負債契約を変 更し, SPCに対して追加融資がなされる. 金融機関が 事業継続を決定した場合, SPC と金融機関の間の負債 契約が変更され，金融機関と SPCの間にサービス対価 $R$ を返済額とする新しい負債契約が結ばれる. 仮定 (4) が成立するため, 新しい負債契約を締結する場合, 金 融機関は初期負債契約における債権を一部放棄しなけ ればならない。第 2 期に SPC はサービス対価 $R$ を獲得 するが，サービス対価は新しい負債契約の返済に充当 される.その結果, SPCは事業を継続することができ る. 本研究全体を通じて, PFI事業は外部経済性を有 し，プロジェクトの追加費用 $C$ が確定しても，事業の 継続が社会的にみて効率的である場合を考える。

最後に, 本研究では負債契約におけるモラルハザー ド問題に分析の焦点を絞るために,

$$
\begin{aligned}
& p_{H} R+\left(1-p_{H}\right)(R-C)-I \\
& \geq p_{L} R+\left(1-p_{L}\right)(R-C)-V
\end{aligned}
$$

を仮定する。条件 (6) は, $\mathrm{SPC}$ が努力水準 $e_{H}$ を選択し た時のプロジェクトの期待利潤が， $e_{L}$ を選択した時の 期待利潤よりも大きいことを表している. 条件 (6) は成 立しない場合には，そもそもモラルハザードが問題と なることはない. 仮定 $(6)$ を展開すれば

$$
\Delta=\Delta p C-B \geq 0
$$

となる.ただし, $\Delta p=p_{H}-p_{L}$ である. 仮定 (7) の左 辺 $\Delta$ はモラルハザードの社会的費用を表している. 


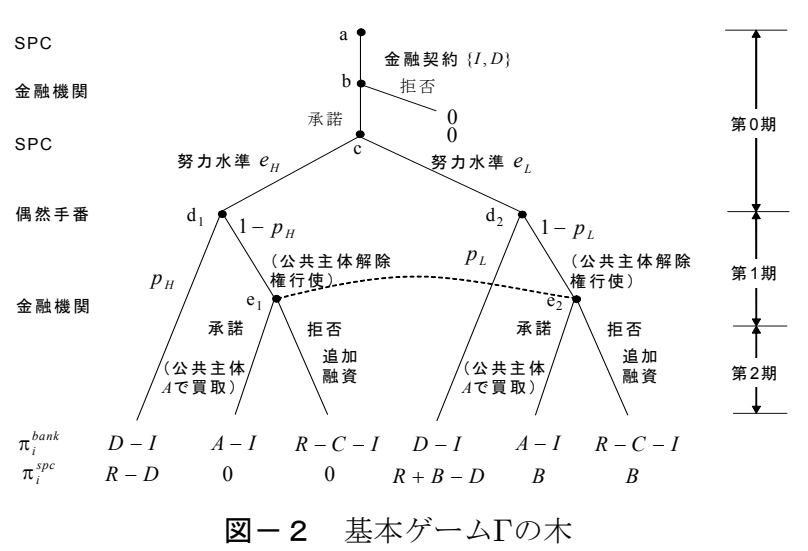

\section{(2) 定式化}

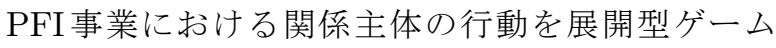
$\Gamma=(K, P, p, U, \pi)$ を用いて表そう。この展開型ゲー ムの基本的要素を以下に整理しておこう。ゲームの木 $K$ を図一2のように構成する． $P_{0}$ を偶然手番全体の集 合， $P_{s p c}, P_{b a n k}$ をそれぞれ $\mathrm{SPC}$ と金融機関の手番の集 合とすると, プレイヤー分割 $P=\left[P_{0}, P_{s p c}, P_{b a n k}\right]$ は

$$
P_{0}=\left\{d_{1}, d_{2}\right\}, P_{s p c}=\{a, c\}, P_{b a n k}=\left\{b, e_{1}, e_{2}\right\}
$$

である. $p_{i}(i=H, L)$ は事業破綻が生起しない確率を表 す. $U_{s p c}, U_{b a n k}$ は SPC と金融機関の情報分割であり, このゲームの情報分割 $U=\left[U_{0}, U_{s p c}, U_{b a n k}\right]$ は，

$$
\begin{aligned}
& U_{0}=\left[u_{0}^{1}, u_{0}^{2}\right]=\left[\left\{d_{1}\right\},\left\{d_{2}\right\}\right] \\
& U_{s p c}=\left[u_{s p c}^{1}, u_{s p c}^{2}\right]=[\{a\},\{c\}] \\
& U_{\text {bank }}=\left[u_{\text {bank }}^{1}, u_{\text {bank }}^{2}\right]=\left[\{b\},\left\{e_{1}, e_{2}\right\}\right]
\end{aligned}
$$

で表される. 同図において, 破線は情報集合を表して いる. 利得関数 $h$ は，図一 2 に示寸とおりである. 基本 ゲームГは以下の手順で進行する. 寸なわち，1）外生 的に与えられたサービス対価 $R$ と買取価格 $A$ のもとで, $\mathrm{SPC}$ が金融機関に対して, 初期融資額 $I$ と返済額 $D$ に 関する負債契約を提案する（ノード $a ）$ ．2）金融機関 がSPCの提案に対して，受諾するか拒否するかを決め る(ノードb)．金融機関が提案を拒否した場合は，全

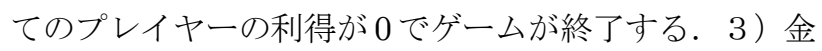
融機関が受諾した場合, 初期融資が行われ, 施設が建 設される.また, $\mathrm{SPC}$ は努力水準 $e_{i}$ を決定する（ノー ドc). 努力水準 $e_{H}$ が選択された場合, 運営費用 $B$ が施 設運営のために支出される。 $e_{L}$ が選択された場合, 資 金 $B$ が私的利益のために支出される。ついで，第 1 期 に進展し，4）確率 $p_{H}, p_{L}$ で追加投資の有無が確定す る（ノード $d_{1}$ 及び $d_{2} ）$ ．5）第 1 期に追加融資が必要 となった場合, 公共主体は事業権契約の解除を宣言す る. 6 ）金融機関が公共主体の事業権解除を拒否する 場合，SPC と金融機関の間で追加融資に関する再交涉
が行われる，金融機関が事業継続を選択したした場合， 新しい負債契約が締結され第 2 期に進む(ノード $e_{1}$ 及 び $\left.e_{2}\right)$ ．７）金融機関が公共主体の解除権行使を受諾す れば，公共主体は金融機関に補償金 $A$ を支払い，事業 資産を買い取る（ノード $e_{1}$ 及び $e_{2}$ ）．8）公共主体は 新しい事業者を決定する（もしくは，直轄で運営する） かを決定する．9）事業が継続した場合, 第 2 期に, 公 共主体から SPCにサービス対価Rが支払われる. SPC が金融機関に返済金 $D$ を支払い，事業が完了寸る.

基本ゲームГは，ゲームのルールがプレイヤー間の共

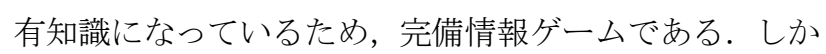

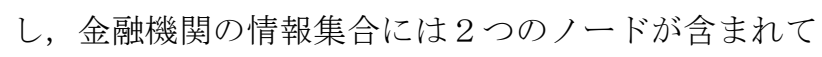
いるため不完全情報ゲームである。基本ゲームの部分 ゲーム完全ナッシュ均衡解 20 )を求めよう. 基本ゲーム の均衡解を求めるために, 偶然手番により状態変数が 確定し, 事業が継続できるかどうかが決定されるノー ド $e_{1}, e_{2}$ 以降の部分ゲームに着目しよう. 事業が破綻し た場合，金融機関は公共主体の事業権解除行使を受諾 するか拒否するかを決定する問題を考える，金融機関 が公共主体の事業権解除を拒否寸る場合, 債権の一部 を放棄し, 追加融資をしないと, 事業の継続が不可能 となる，仮定 $(2),(4)$ より, 次式が成立する.

$$
R \geq C
$$

仮定 $(8)$ より，金融機関が事業を継続することにより, 債権の一部を回収できるため, 事業を継続する意思を 持つ.すなわち，金融機関が事業を清算するという均 衡解は出現しない，金融機関が負債契約の変更におい て, 完全な交涉力を持つ場合, 新しい返済額 $D^{\prime}$ は

$$
D^{\prime}=R
$$

に決定される。この時, 金融機関が獲得できる利潤 $\pi_{i}^{\text {bank }}(C)(i=H, L)$ は

$$
\pi_{i}^{\text {bank }}(C)=R-C-I<0
$$

と表される.一方，金融機関が公共主体の事業権解除 を受諾する場合，金融機関が獲得する利潤は

$$
\pi_{i}^{b a n k}(C)=A-I
$$

となる。したがって, 金融機関が公共主体の事業権解 除を受諾する条件は

$$
A-I \geq R-C-I
$$

と表される. 式(12)の左辺は, 金融機関が解除権の行 使を受諾する場合の利得を, 右辺は解除権の行使を拒 否寸る場合の利得を表している.

\section{（3）基本ゲームの均衡解}

\section{a) $A<R-C$ が成立する場合（Case A)}

本ケースでは，金融機関が公共主体の事業権解除を 拒否する.まず, 第 1 期に, 事業破綻が生起しない場合 
を考えよう．SPCは金融機関から追加融資を受けなく ても事業を完了できる. SPCが努力水準 $e_{H}$ を選択した 場合, 金融機関の融資額 $I$ は, 建設費用 $V$ と運営費用 $B$ に支出される．努力水準 $e_{L}$ を選択した場合，運営費用 Bを私的利益に利用する。したがって，SPCが事業に より獲得する利潤 $\pi_{i}^{s p c}(0)(i=H, L)$ は

$$
\begin{aligned}
& \pi_{H}^{s p c}(0)=R-D \\
& \pi_{L}^{s p c}(0)=R+B-D
\end{aligned}
$$

と表される。一方，第 1 期に事業が破綻した場合，事業 の継続のため追加融資 $C$ が必要となる. 仮定 $(8)$ より, 金融機関は事業継続に応じるが, 式(4)が成立するため に，初期融資契約における返済額は変更される. 契約 変更において金融機関は再交渉において交渉力を有し, 第 2 期のサービス対価 $R$ はすべて金融機関が獲得する. したがって，第 2 期の $\operatorname{SPC} の$ 利潤 $\pi_{i}^{s p c}(C)(i=H, L)$ は

$$
\begin{aligned}
& \pi_{H}^{s p c}(C)=0 \\
& \pi_{L}^{s p c}(C)=B
\end{aligned}
$$

となる．金融機関の利潤 $\pi_{i}^{b a n k}(0), \pi_{i}^{b a n k}(C)(i=H, L)$ は，それぞれ次式で表せる。

$$
\begin{aligned}
& \pi_{i}^{\text {bank }}(0)=D-I \\
& \pi_{i}^{\text {bank }}(C)=R-I-C<0
\end{aligned}
$$

金融機関の期待利潤 $\Pi_{i}^{s p c}(D)(i=H, L)$ は

$$
\begin{aligned}
& \Pi_{H}^{\text {bank }}(D)=p_{H} D+\left(1-p_{H}\right)(R-C)-I(16 \mathrm{a}) \\
& \Pi_{L}^{b a n k}(D)=p_{L} D+\left(1-p_{L}\right)(R-C)-I(16 \mathrm{~b})
\end{aligned}
$$

となる. 公共主体が負担する金額は常に一定值 $R$ とな る. 第 0 期に遡り，SPCが努力水準を選択する問題を 考える. 返済額 $D$ を所与として努力水準 $e_{i}(i=H, L)$ を選択した場合の期待利潤 $\Pi_{i}^{s p c}(D)(i=H, L)$ は

$$
\begin{aligned}
& \Pi_{H}^{s p c}(D)=p_{H}(R-D) \\
& \Pi_{L}^{s p c}(D)=p_{L}(R-D)+B
\end{aligned}
$$

となり, 社会的最適な努力水準 $e_{H}$ が選択されるための 誘因両立条件は

$$
\begin{aligned}
& \Pi_{H}^{s p c}(D)-\Pi_{L}^{s p c}(D) \\
& =\Delta p(R-D)-B \geq 0
\end{aligned}
$$

と表される。第 0 期において, SPCが努力水準を決定 する前に，金融機関が返済額 $D$ を決定する. SPCが選 択した努力水準が既知である時，SPCが選択した努力 水準 $e_{H}$ に対して, 金融機関の期待利潤がゼロとなる臨 界的返済額 $D_{H}$ は，式 $(16 \mathrm{a})$ より

$$
D_{H}=\frac{I-\left(1-p_{H}\right)(R-C)}{p_{H}}
$$

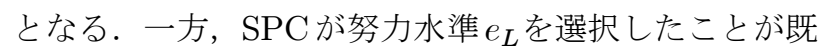
知である時, 臨界的返済額 $D_{L}$ は, 式 $(16 \mathrm{~b}) よ り$

$$
D_{L}=\frac{I-\left(1-p_{L}\right)(R-C)}{p_{L}}
$$

となる.ここで, $D_{L}-D_{H}=\{\Delta p(I-R+C)\} / p_{H} p_{L}>$ 0 が成立する. 臨界的返済額 $D_{H}$ に対して, SPCが努力 水準 $e_{H}$ を選択するための条件は

$$
(I+C>) R \geq \nu_{1}
$$

と表される（付録 1$)$ 参照）。ただし， $\nu_{1}=I+(1-$ $\left.p_{H}\right) C+\frac{p_{H} B}{\Delta p}$ である. 一方, $\mathrm{SPC}$ が努力水準 $e_{L}$ を選択 する条件は

$$
\nu_{1}>R \geq \nu_{2}
$$

と表される (付録 1 ) 参照). ただし, $\nu_{2}=I+\left(1-p_{L}\right) C$ であり，事業者が努力水準 $e_{L}$ を選択する場合の事業の 成立条件を表している。したがって，本ケースでは以 下の均衡解が存在する。

$$
\begin{cases}\text { 均衡解 } \mathrm{A} & D^{*}=D_{H}, e^{*}=e_{H} \\ & (\text { 式 }(21) \text { が成立する時 }) \\ \text { 均衡解 } \mathrm{B} & D^{*}=D_{L}, e^{*}=e_{L} \\ & (\text { 式 }(22) \text { が成立する時 })\end{cases}
$$

すなわち, 均衡解 $\mathrm{A}$ では, $\mathrm{SPC}$ が努力水準 $e_{H}$ を選択し, 社会的最適な契約が実現できる。一方，均衡解Bでは， $\mathrm{SPC}$ が努力水準 $e_{L}$ を選択し, 社会的最適な契約が実現 しない。均衡解 $\mathrm{A}, \mathrm{B}$ において $\mathrm{SPC}$ の期待利潤は

$$
\begin{aligned}
& \Pi_{A}^{s p c}=R-I-\left(1-p_{H}\right) C \\
& \Pi_{B}^{s p c}=R-I-\left(1-p_{L}\right) C+B
\end{aligned}
$$

となる。

\section{b) $A \geq R-C$ が成立する場合（Case B)}

本ケースでは，金融機関が公共主体による事業権解 除を受け入れる。公共主体は事業権を解除し, 金融機 関から買取価格 $A$ で事業を買い取る. 公共主体は改め て新しいSPC と事業権契約を締結する. 新規 SPCが事 業を継続し, 追加費用と同額のサービス対価 $C$ を受け 取る. 公共主体は既存 SPC あるいは新規 SPC と事業権 契約を締結しても, 既存 SPCが獲得する利潤は変わら ない.したがって, SPCが獲得する利潤は, Case A と 同様に式 (13a)-(14b) で表せる. 金融機関は事業権が解 除されても, 公共主体より買取り価格 $A$ を獲得できる. したがって，金融機関は，利潤

$$
\begin{aligned}
& \pi_{i}^{b a n k}(0)=D-I(i=H, L) \\
& \pi_{i}^{b a n k}(C)=A-I(i=H, L)
\end{aligned}
$$

を獲得する。したがって, 金融機関の期待利潤 $\Pi_{i}^{\text {bank }}(D)(i=H, L)$ は

$$
\begin{aligned}
& \Pi_{H}^{\text {bank }}(D)=p_{H} D+\left(1-p_{H}\right) A-I \\
& \Pi_{L}^{\text {bank }}(D)=p_{L} D+\left(1-p_{L}\right) A-I
\end{aligned}
$$

と表せる．最後に，公共主体が負担する金額は

$$
\begin{aligned}
& \pi_{i}^{p u b}(0)=R(i=H, L) \\
& \pi_{i}^{p u b}(C)=A+C(i=H, L)
\end{aligned}
$$


となる。第 0 期に遡り， $\mathrm{SPC}$ が努力水準を選択する問題 を考える. 返済額 $D$ を所与とした努力水準 $e_{i}(i=H, L)$ を選択した場合の期待利潤 $\Pi_{i}^{s p c}(D)(i=H, L)$ は, Case Aの場合と同様に式 (17a),(17b) で表される.また, SPC が努力水準 $e_{H}$ を選択するための誘因両立条件は式 (18) で表される. $\mathrm{SPC}$ の努力水準 $e_{i}(i=H, L)$ が既知であ る時, $\mathrm{SPC}$ が選択した努力水準 $e_{i}(i=H, L)$ に対して, 金融機関の期待利潤がゼロとなる臨界的返済額 $D_{i}^{t}(i=$ $H, L)$ は，式(25a),(25b)より

$$
\begin{aligned}
& D_{H}^{t}=\frac{I-\left(1-p_{H}\right) A}{p_{H}} \\
& D_{L}^{t}=\frac{I-\left(1-p_{L}\right) A}{p_{L}}
\end{aligned}
$$

となる，つぎに，臨界的返済額 $D_{H}^{t}$ の下で， $\mathrm{SPC}$ が努 力水準 $e_{H}$ を選択する条件は

$$
(I+C>) R \geq \frac{I-\left(1-p_{H}\right) A}{p_{H}}+\frac{B}{\Delta p}=\nu_{3}
$$

と表される (付録 1$)$ 参照). ただし, $\nu_{3}=\frac{I-\left(1-p_{H}\right) A}{p_{H}}+$ $\frac{B}{\Delta p}$ である. 一方,

$$
\nu_{3}>R \geq \nu_{4}
$$

が成立する時, $\mathrm{SPC}$ が努力水準 $e_{L}$ を選択する（付録 1) 参照 $)$. ただし, $\nu_{4}=\frac{I-\left(1-p_{L}\right) A}{p_{L}}$ であり, 事業者が努力 水準 $e_{L}$ を選択する場合の事業の成立条件を表している.

本ケースでは，以下のような均衡解が存在する.

$$
\begin{cases}\text { 均衡解 } \mathrm{C} & D^{*}=D_{H}^{t}, e^{*}=e_{H} \\ & (\text { 式 }(28) \text { が成立する時 }) \\ \text { 均衡解 } \mathrm{D} & D^{*}=D_{L}^{t}, e^{*}=e_{L} \\ & (\text { 式 }(29) \text { が成立する時 })\end{cases}
$$

すなわち, 均衡解 $\mathrm{C}$ では, $\mathrm{SPC}$ が努力水準 $e_{H}$ を選択し, 社会的最適な契約が実現できる. 一方, 均衡解 Dでは, $\mathrm{SPC}$ が努力水準 $e_{L}$ を選択し, 社会的最適な契約が実現 しない. また均衡解 C,D において $\mathrm{SPC}$ が獲得する期待 利潤は次式で表される。

$$
\begin{aligned}
& \Pi_{C}^{s p c}=p_{H} R-I+\left(1-p_{H}\right) A \\
& \Pi_{D}^{s p c}=p_{L} R-I+\left(1-p_{L}\right) A+B
\end{aligned}
$$

\section{4. 競争入札制度と均衡解}

\section{（1）競争入札制度}

PFI事業を開始するにあたり，事業権契約に関する 競争入札が実施され, 最小のサービス対価を提示した 事業者が SPCに選ばれると考えよう。このような競争 入札によって選択される解を競争入札解と呼ぶ. 現実 のPFI事業では, 競争入札に参加する事業者が, さま ざまな事業提案を提出し, その総合評価により落札者 が決定される場合が多い。しかし, 総合評価で用いら れる重みは, 評価項目とサービス対価とのトレードオ フを表現するものであり, 結果的にはサービス対価と
して金銭評価されていると考えることができる．以下 では, サービス対価を巡って入札者の間で完全競争が 実現している場合を考える。前稿14)でも言及したよう に, PFI事業権契約に関する競争入札に参加するため に, 事業提案の作成費等, 無視できない取引費用が発 生する. したがって, 競争入札に参加する事業者の数 が限られる場合が多い。このため, 競争入札の参加者 の間で，完全競争が実現する保証はない。このような 競争入札メカニズムに関しても研究28)-29)が蓄積され ている. しかし, 本研究の目的は, 事業権契約の構造を 分析することにあり, 事業権契約の入札に当たり完全 競争が実現すると仮定する. 競争入札では, 入札に参 加する事業の間で過度の競争が働き, 高い努力水準を 選択する事業者が SPCに選ばれない可能性がある。こ のような過度の競争を防ぐため, 入札価格の最低価格 に制約を設けた最低予定価格制度を考える。この場合， 最低価格を入札実施にあたって公表する必要はない. 入 札価格の下限值制約の存在と最低予定価格の意味のみ を, 入札参加者に通知すればいい。このような最低予 定価格制度の下で決定される均衡解を最低価格入札解 と呼ぶこととする。

\section{（2）競争入札解}

いま, PFI事業を開始するにあたり, 公共主体が事前 に事業破綻時の買取価格 $A$ を公表する. その上で, 事業 権契約に関する競争入札が実施され, 最小のサービス対 価 $R$ を入札した事業者が事業権を獲得すると考えよう. この場合，事業の買取価格 $A$ の值により，1） Case A が成立する範囲の均衡解の中で, 最小のサービス対価 を持つ均衡解が競争入札解となる場合，2）Case Bの 成立する範囲の中で, 競争入札解となる場合, 3) Case A と Case B の双方の最低入札価格の中で小さい入札価 格をもつ均衡解が競争入札価格となる場合が存在する.

\section{a）Case Aの均衡解が選択される場合}

事業の買取価格 $A$ に関して

$$
A<\min \left\{\nu_{1}-C, \nu_{2}-C\right\}
$$

が成立する場合を考えよう。この時, 式 $(21)$, あるいは 式(22) を満足する任意の $R$ に対して,$A<R-C$ 感成 立する.すなわち, 事業が破綻したとき, 金融機関の 支援により事業が継続される.

均衡解 $\mathrm{A}$ が成立するような最小のサービス対価（以 下，臨界的サービス対価と呼ぶ） $R_{m i n}^{A}$ は,

$$
R_{\min }^{A}=\nu_{1}
$$

と表される。同様に, 均衡解 Bが成立するような臨界 的サービス対価 $R_{\text {min }}^{B}$ は次式で表される.

$$
R_{\min }^{B}=\nu_{2}
$$


競争入札によりサービス対価が決定される場合，実行 可能の範囲の中で最低価格 $\nu^{*}$ を入札した事業者が事業 権を獲得する。したがって, 競争入札解は

$$
\begin{cases}\text { 均衡解 } \mathcal{A} & D^{*}=D_{L}^{*}, e^{*}=e_{L} \\ & \nu^{*}=\nu_{2} \\ \text { 均衡解 } \mathcal{B} & D^{*}=D_{H}^{*}, e^{*}=e_{H} \\ & \nu^{*}=\nu_{1}\end{cases}
$$

となる (付録 $2 ）$ 参照)。ただし, $D_{H}^{*}, D_{L}^{*}$ は, それぞ れ入札価格 $\nu_{1}, \nu_{2}$ に対する初期融資契約の返済額であり

$$
\begin{aligned}
& D_{H}^{*}=I+\left(1-p_{H}\right) C-\frac{\left(1-p_{H}\right) B}{\Delta p} \\
& D_{L}^{*}=I+\left(1-p_{L}\right) C
\end{aligned}
$$

と表せる。 なお，各均衡解が成立する条件は表－20 ように整理できる（付録 2 ）参照）。競争入札解 $\mathcal{A}$ で は, $\mathrm{SPC}$ が努力水準 $e_{L}$ を選択し，モラルハザードが発 生する. 一方, 競争入札解 $\mathcal{B}$ では, $\mathrm{SPC}$ が努力水準 $e_{H}$ を選択し，効率的な契約が実現できる.

\section{b) Case Bの均衡解が選択される場合}

事業の買取価格 $A$ に関して

$$
A \geq \max \left\{\nu_{1}-C, \nu_{2}-C\right\}
$$

が成立する場合を考えよう。この時, 式 (28), あるいは 式(29) を満足する任意の $R$ に対して, $A \geq R-C$ が成 立する. 寸なわち, 事業が破綻したとき, 金融機関は, 公共主体による解除権の行使に同意する。まず，均衡 解 $\mathrm{C}$ が成立するような臨界的サービス対価 $R_{m i n}^{C}$ は

$$
R_{\min }^{C}=\nu_{3}
$$

と表される。同様に, 均衡解 D が成立するような臨界 的サービス対価 $R_{\text {min }}^{D}$ は

$$
R_{\min }^{D}=\nu_{4}
$$

となる、したがって，競争入札解は

$$
\begin{cases}\text { 均衡解 } \mathcal{C} & D^{*}=D_{L}^{t}, e^{*}=e_{L} \\ & \nu^{*}=\nu_{4} \\ \text { 均衡解 } \mathcal{D} & D^{*}=D_{H}^{t}, e^{*}=e_{H} \\ & \nu^{*}=\nu_{3}\end{cases}
$$

となる（付録 2 ）参照）。各均衡解が成立する条件は

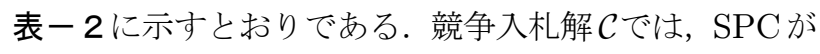
努力水準 $e_{L}$ を選択し，モラルハザードが発生する。一 方, 競争入札解 Dでは, $\mathrm{SPC}$ が努力水準 $e_{H}$ を選択し, 社会的最適な契約が実現できる。

\section{c）Case A,Bから競争入札解が選択される場合}

最後に，事業の買取価格 $A$ が

$$
\max \left\{\nu_{1}-C, \nu_{2}-C\right\}>A \geq \min \left\{\nu_{1}-C, \nu_{2}-C\right\}
$$

を満足する場合をとりあげる。まず, $\nu_{1}-C>A \geq$ $\nu_{2}-C$ が成立すると仮定しよう.この場合, 努力水準 $e_{H}$ が選択される臨界的サービス対価は $\nu_{1}$ となり, 努力 水準 $e_{L}$ が選択される臨界的サービス対価は $\nu_{4}$ となる. $\nu_{1}>\nu_{2} \geq \nu_{4}$ が成立するため（付録 3 ）参照），この 場合の競争入札価格 $\nu^{*}$ は $\nu_{4}$ である. つぎに, $\nu_{2}-C>$ $A \geq \nu_{1}-C$ が成立する場合を考えよう。この場合には, 努力水準 $e_{H}$ が選択される臨界的サービス対価は $\nu_{3}$ とな り, 努力水準 $e_{L}$ が選択される臨界的サービス対価は $\nu_{2}$ となる. $\nu_{2}>\nu_{1} \geq \nu_{3}$ が成立するため（付録 3 ）参照）, 競争入札価格 $\nu^{*}$ は $\nu_{3}$ である. すなおち, 本ケースでは, 以下の競争入札解が存在する.

$$
\begin{cases}\text { 均衡解 } \mathcal{E} & D^{*}=D_{L}^{t}, e^{*}=e_{L} \\ & \nu^{*}=\nu_{4} \\ \text { 均衡解 } \mathcal{F} & D^{*}=D_{H}^{t}, e^{*}=e_{H} \\ & \nu^{*}=\nu_{3}\end{cases}
$$

となる. 各均衡解が成立する条件を表ー 2 に示す。競 争入札解 $\mathcal{E}$ では, $\mathrm{SPC}$ が努力水準 $e_{L}$ を選択し, モラル

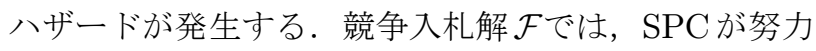
水準 $e_{H}$ を選択し, 社会的最適な契約が実現できる.

なお，以上で議論した競争入札解を表－2に一括し て整理している.さらに，同表には各競争入札解にお いて, SPCが獲得する期待利潤 $\Pi^{s p c}$ と公共主体が支払 う期待支払額 $\Pi^{p u b}$ も示している.

\section{（3）最低価格入札解}

競争入札解 $\mathcal{A}, \mathcal{C}, \mathcal{E}$ では, $\mathrm{SPC}$ が努力水準 $e_{L}$ を選択す るというモラルハザードが発生する。そこで，モラル ハザードを抑制するために，入札価格に下限值を設定 する最低予定価格制度をとりあげよう。本制度の下で は，競争入札において最低予定価格を超える入札価格 の中で，最も小さな入札価格を提示した事業者が SPC として選択される。

競争入札解 $\mathcal{A}$ に対して, 最低入札価格 $\tilde{R}=\nu_{1}$ を設定 しょう。この時, 最低価格入札解として,

$\left\{\right.$ 最低価格入札解 $\mathcal{A}^{\prime} \quad \tilde{D}=D_{H}^{*}, \tilde{e}=e_{H}, \tilde{R}=\nu_{1}$

が成立する. 最低価格入札解では，モラルハザードが 発生せず, 社会的最適な契約が実現する. 最低価格入 札解において SPCが獲得する期待利潤は

$$
\tilde{\Pi}_{\mathcal{A}}^{s p c}=\tilde{R}-\left\{I+\left(1-p_{H}\right) C\right\}=\frac{p_{H} B}{\Delta p}
$$

となる．すなわち，SPCのモラルハザードを抑制する ために, 公共主体は期待費用だけでなく $\frac{p_{H} B}{\Delta p}$ を付加的 に支払う。公共主体が負担する期待支払額は

$$
\tilde{\Pi}_{\mathcal{A}}^{p u b}=\nu_{1}=I+\left(1-p_{H}\right) C+\frac{p_{H} B}{\Delta p}
$$

となる. 同様に, 競争入札解 $\mathcal{C}$ に対して最低入札価格 $\tilde{R}=\nu_{3}$ を, 競争入札解 $\mathcal{E} に$ 対して, 最低入札価格 $\tilde{R}=\nu_{1}$ を設定しよう。この時, 最低価格入札解

$\left\{\begin{array}{cc}\text { 最低価格入札解 } \mathcal{C}^{\prime} & \tilde{D}=D_{H}^{t}, \tilde{e}=e_{H}, \tilde{R}=\nu_{3} \\ \text { 最低価格入札解 } \mathcal{E}^{\prime} & \tilde{D}=D_{H}^{*}, \tilde{e}=e_{H}, \tilde{R}=\nu_{1}\end{array}\right.$ 
表一 2 基本ゲームの競争入札解

\begin{tabular}{c|c|c|c|c|c|c}
\hline 競争入札解 & 成立条件 & $D^{*}$ & $e^{*}$ & $\nu^{*}$ & $\Pi^{s p c}$ & $\Pi^{p u b}$ \\
\hline $\mathcal{A}$ & $\nu_{1}>\nu_{2}, A<\nu_{2}-C$ & $D_{L}^{*}$ & $e_{L}$ & $\nu_{2}$ & $B$ & $\nu_{2}$ \\
$\mathcal{B}$ & $\nu_{1} \leq \nu_{2}, A<\nu_{1}-C$ & $D_{H}^{*}$ & $e_{H}$ & $\nu_{1}$ & $\frac{p_{H} B}{\Delta p}$ & $\nu_{1}$ \\
$\mathcal{C}$ & $\nu_{1}>\nu_{2}, A \geq \nu_{1}-C$, あるいは $\nu_{1} \leq \nu_{2}, A>I-\frac{p_{H} p_{L} B}{(\Delta p)^{2}} \geq \nu_{2}-C$ & $D_{L}^{t}$ & $e_{L}$ & $\nu_{4}$ & $B$ & $\nu_{2}$ \\
$\mathcal{D}$ & $\nu_{1} \leq \nu_{2}, I-\frac{p_{H} p_{L} B}{(\Delta p)^{2}} \geq A \geq \nu_{2}-C$ & $D_{H}^{t}$ & $e_{H}$ & $\nu_{3}$ & $\frac{p_{H} B}{\Delta p}$ & $\nu_{1}$ \\
$\mathcal{E}$ & $\nu_{1}-C>A \geq \nu_{2}-C$ & $D_{L}^{t}$ & $e_{L}$ & $\nu_{4}$ & $B$ & $\nu_{2}$ \\
$\mathcal{F}$ & $\nu_{2}-C>A \geq \nu_{1}-C$ & $D_{H}^{t}$ & $e_{H}$ & $\nu_{3}$ & $\frac{p_{H} B}{\Delta p}$ & $\nu_{1}$ \\
\hline
\end{tabular}

注） $\Pi^{s p c}$ の闌は, $\mathrm{SPC}$ の期待利潤を, $\Pi^{p u b}$ は公共主体の期待支払い額を表している. また, $D_{H}^{*}=I+\left(1-p_{H}\right) C-\frac{\left(1-p_{H}\right) B}{\Delta p}$, $D_{L}^{*}=I+\left(1-p_{L}\right) C=\nu_{2}, \quad D_{H}^{t}=\frac{I-\left(1-p_{H}\right) A}{p_{H}}, \quad D_{L}^{t}=\frac{I-\left(1-p_{L}\right) A}{p_{L}}=\nu_{4}, \quad \nu_{1}=I+\left(1-p_{H}\right) C+\frac{p_{H} B}{\Delta p}=D_{H}^{*}+\frac{B}{\Delta p}$, $\nu_{3}=\frac{I-\left(1-p_{H}\right) A}{p_{H}}+\frac{B}{\Delta p}=D_{H}^{t}+\frac{B}{\Delta p}$ である.

が成立する．これらの最適価格入札解において SPCが 獲得する期待利潤は

$$
\tilde{\Pi}_{\mathcal{C}}^{s p c}=\tilde{\Pi}_{\mathcal{E}}^{s p c}=\frac{p_{H} B}{\Delta p}
$$

となる．公共主体が負担する期待支払額は

$$
\tilde{\Pi}_{\mathcal{C}}^{p u b}=\tilde{\Pi}_{\mathcal{E}}^{p u b}=\nu_{1}
$$

となる. なお, 競争入札解 $\mathcal{B}, \mathcal{D}, \mathcal{F}$ が成立する場合, $\mathrm{SPC}$ のモラルハザードは発生しない. 以上の競争入札解の 内, 競争入札解 $\mathcal{B}$ では競争入札価格は $\nu_{1}$ に, 競争入札解 $\mathcal{D}, \mathcal{F}$ では，競争入札価格は $\nu_{3}$ となる.これらの競争入 札解においては，競争入札価格を最低入札価格に設定 すれば，競争入札解を最低価格入札解と考えることが できる．したがって，いずれの最低価格入札解におい ても， $\mathrm{SPC}$ が獲得する期待利潤は $p_{H} B / \Delta p$ で，公共主 体が負担する期待支払額は $\nu_{1}$ となる。このように，最 低価格入札解では，社会的効率性を確保できるが，公 共主体が SPCに期待プロジェクト費用以上に追加費用 （準レント） $p_{H} B / \Delta p$ を支払うことが必要となる. 追加 費用は，公共主体から SPC，金融機関への所得移転で あり, 最低価格入札解は財務的効率性を達成できない.

\section{（4）金融機関によるモラルハザードの可能性}

以上の議論では，SPCのモラルハザードの可能性に 関してのみ議論をしてきた。しかし，金融機関と公共主 体との関係の中で，金融機関にモラルハザードが発生す る可能性が存在する. 特に, 最低価格入札解では, SPC のモラルハザードを防止するために公共主体が SPCに 準レント $p_{H} B / \Delta p$ を支出する。最低価格入札解では, 準レントがすべて SPCに帰属することを想定していた. しかし，金融機関に交涉力がある場合，金融機関に準 レントを没収しようとする動機が生まれる。このよう な機会主義的な行動により金融機関は私的便益を獲得 することが可能であり，その行動は公共主体にとって 立証不可能である.この意味で，金融機関のモラルハ ザードと考えることができる。

いま，初期融資契約において，金融機関が完全な交 涉力をもつ場合を考えよう。4（３）で分析したよう
に，最低価格入札により決定するサービス対価 $\tilde{R} は$

$$
\begin{cases}\tilde{R}=\nu_{3} & A \geq \nu_{1}-C \\ \tilde{R}=\nu_{1} & \nu_{1}-C>A\end{cases}
$$

と表せる．まず， $A<\nu_{1}-C$ が成立する場合を考えよ う。この場合, 最低入札価格解では入札価格が $\nu_{1} に$, 返 済額は $D_{H}^{*}$ に決定される. 前述したように, 初期契約 に返済額 $D_{H}^{*}$ が記述される場合には，誘因両立条件 $(28)$ が成立し, SPCは努力水準 $e_{H}$ を選択する。すなわち, $\mathrm{SPC}$ はモラルハザードを起こさない.さらに, SPCに 準レント $p_{H} B / \Delta p$ が帰属する。一方で，金融機関の期 待利潤は0である. しかし, 事業権契約が締結される段 階で, 最低入札価格に準レントが含まれることは, SPC と金融機関双方にとって共有知識となっている．金融 機関が完全な交涉力を持つ場合，金融機関に準レント のす心゙てを獲得しようとする誘因が働く、いま，金融機 関が返済額として $D_{H}^{*}$ でなく, 準レントも含めた返済額 $D^{\circ}=\nu_{1}=D_{H}^{*}+\frac{p_{H} B}{\Delta p}$ を要求する場合を考える. 返済 額 $D^{\circ}$ の下で, $\mathrm{SPC}$ が努力水準 $e_{H}$ を選択する誘因両立 条件 (18) は $\Delta p\left(\nu_{1}-D^{\circ}\right)-B=-B<0$ となり, $\mathrm{SPC}$ は努力水準 $e_{H}$ を選択する誘因を持たない. $\mathrm{SPC}$ は努力 水準 $e_{L}$ を選択するが, $\operatorname{SPC}$ の期待利潤 $\bar{\Pi}_{L}^{s p c}\left(D^{\circ}\right)$ は

$$
\bar{\Pi}_{L}^{s p c}\left(D^{\circ}\right)=p_{L}\left(\nu_{1}-D^{\circ}\right)+B=B
$$

となり，金融機関が追加利潤をすべて没収する。金融 機関のモラルハザードが発生する条件は

$$
\begin{aligned}
& \nu_{1}>\nu_{2}, A<\nu_{2}-C \text { の場合 } \\
& \nu_{1} \geq \nu_{4}, \nu_{1}-C>A \geq \nu_{2}-C \text { の場合 }
\end{aligned}
$$

と表せる，条件 (42a),(42b) が成立しない場合，返済額 $\nu_{1}$ は努力水準 $e_{L}$ が選択される臨界的返済額 $\nu_{2}$ あいは $\nu_{4}$ より小さいため, 金融機関の期待利潤は 0 以下にな る.したがって, 金融機関のモラルハザードは発生しな い. 一方，条件 $(42 \mathrm{a}),(42 \mathrm{~b})$ が成立するとき，金融機関 
表ー3 金融機関のモラルハザード問題

\begin{tabular}{|c|c|c|c|c|c|c|}
\hline \multicolumn{2}{|r|}{ 買取価格 $A$} & $\begin{array}{l}\text { 入札 } \\
\text { 価格 }\end{array}$ & $\begin{array}{l}\text { 臨界的サービス } \\
\text { 対価の順序関係 }\end{array}$ & 返済額 & $\begin{array}{c}\text { モラルハザード } \\
(\mathrm{SPC})\end{array}$ & $\begin{array}{c}\text { モラルハザード } \\
\text { (金融機関) }\end{array}$ \\
\hline \multirow[t]{3}{*}{$A<\nu_{1}-C$} & \multirow{2}{*}{$A<\min \left\{\nu_{1}-C, \nu_{2}-C\right\}$} & \multirow[t]{3}{*}{$\nu_{1}$} & $\nu_{1}>\nu_{2}$ & $\nu_{1}$ & $\bar{x}$ & $\bar{x}$ \\
\hline & & & $\nu_{1} \leq \nu_{2}$ & $D_{H}^{*}$ & O & O \\
\hline & $\nu_{1}-C>A \geq \nu_{2}-C$ & & $\nu_{1}>\nu_{4}$ & $\nu_{1}$ & $\times$ & $\times$ \\
\hline \multirow[t]{3}{*}{$A \geq \nu_{1}-C$} & \multirow[t]{2}{*}{$A \geq \max \left\{\nu_{1}-C, \nu_{2}-C\right\}$} & \multirow[t]{3}{*}{$\nu_{3}$} & $\nu_{3}>\nu_{4}$ & $\nu_{3}$ & $\times$ & $\times$ \\
\hline & & & $\nu_{3} \leq \nu_{4}$ & $\overline{D_{H}^{t}}$ & O & $\mathrm{O}$ \\
\hline & $\nu_{2}-C>A \geq \nu_{1}-C$ & & $\nu_{3}<\nu_{2}$ & $D_{H}^{t}$ & O & $\mathrm{O}$ \\
\hline
\end{tabular}

注）モラルハザードの欄で○印はモラルハザードが発生しない場合を，×印はモラルハザードが発生する場合を表す.

が獲得する期待利潤は次式で表される（付録 3）参照）.

$$
\bar{\Pi}_{L}^{b a n k}=\left\{\begin{array}{l}
p_{L} D^{\circ}+\left(1-p_{L}\right)\left(\nu_{1}-C\right)-I \\
=\frac{p_{H} B}{\Delta p}-\Delta p C>0 \\
\left(A<\min \left\{\nu_{1}-C, \nu_{2}-C\right\} \text { の場合 }\right) \\
p_{L} D^{\circ}+\left(1-p_{L}\right) A-I \\
=\left(1-p_{H}\right) p_{L} C-\left(1-p_{L}\right)(I-A) \\
\quad+\frac{p_{H} p_{L} B}{\Delta p}>0 \\
\left(\nu_{1}-C>A \geq \nu_{2}-C \text { 場合 }\right)
\end{array}\right.
$$

つぎに, $I \geq A>\nu_{1}-C$ が成立する場合を考える. 最低価格入札解における入札価格は $\nu_{3}$ であり，返済額 は $D_{H}^{t}$ である。いま，金融機関が返済額として $D_{H}^{t}$ でな く, 準レントも含めた返済額 $D^{\circ \circ}=\nu_{3}=D_{H}^{t}+\frac{B}{\Delta p}$ を要 求した場合を考えよう。本ケースの場合も, 返済額 $D^{\circ \circ}$ の下で，入札価格 $\nu_{3}$ は誘因両立条件 $(18)$ を満足しない. したがって, SPC は努力水準 $e_{L}$ を選択するが， $\mathrm{SPC} の$ 期待利潤 $\bar{\Pi}_{L}^{s p c}\left(D^{\circ \circ}\right)$ は次式で表される.

$$
\bar{\Pi}_{L}^{s p c}\left(D^{\circ \circ}\right)=p_{L}\left(\nu_{3}-D^{\circ \circ}\right)+B=B
$$

すなわち，SPCはモラルハザードを引き起こすが，そ れによる追加利潤はすべて金融機関に吸収される。金 融機関のモラルハザードが発生する条件は

$$
\nu_{3} \geq \nu_{4}, A \geq \max \left\{\nu_{1}-C, \nu_{2}-C\right\} \text { の場合 }
$$

と表せる，条件 (45)が成立するとき，金融機関が獲得 する期待利潤は以下のようになる（付録 3）参照）.

$$
\begin{aligned}
& \bar{\Pi}_{L}^{\text {bank }}=p_{L} D^{\circ \circ}+\left(1-p_{L}\right) A-I \\
& =\frac{p_{L} B}{\Delta p}-\frac{\Delta p(I-A)}{p_{H}}>0
\end{aligned}
$$

以上の分析結果を，表一3にとりまとめている。こ のように，最低入札価格制度では，1）SPCのモラル ハザードを抑制するために，公共主体が準レントを支 払うこと，2）事業が破綻した場合に，公共主体が事業 を固定価格 $A$ で買い取ることが，金融機関のモラルハ ザードの原因になっている，すなわち，金融機関が完全 な交涉力を持つ場合，金融機関に準レントを没収しよ うとするモラルハザードが発生する．金融機関の交渉力 が完全でない場合にも，金融機関と SPCが共謀し，期 待利潤を増加することを目的としたモラルハザードが 発生する可能性がある。しかし，SPCが完全な交涉力
をもつ場合や複数の金融機関で融資に関して競争が行 われる場合，金融機関のモラルハザードが発生しない. 本研究では, 競争入札段階において, SPC と金融機関 の間でリレーションシップがすでに形成されていたこ とを想定している．SPCがほかの金融機関と契約する 場合，多大な交渉などの費用を要するため， SPCがリ レーションシップを離脱する動機を持たない.したがっ て，本研究では金融機関が完全な交涉力を持つことを 想定する. 以上で議論したモラルハザードは，すべて 金融機関のモラルハザードが原因となっている．金融 機関がモラルハザードを引き起こさない限り，SPCの モラルハザードは発生しない。しかし，最低入札価格 制度には，金融機関のモラルハザードを抑止するメカ ニズムが内在していないという限界がある，次章では， $\mathrm{SPC}$ と金融機関のモラルハザードを抑止する方策とし て保証金制度を取り上げる。

\section{5. 保証金ゲーム}

\section{（1）保証金の役割}

PFI 事業の効率性を確保する手段として保証金制度 に着目しよう。公共主体は解除権を有し，事業開始段 階において SPCが自己資金を原資として保証金を公共 主体に預けることが義務付けられる．金融機関からの 借入金を保証金の支払いに充当することは禁止されて いる。ただし，基本ゲームと同様に，保証金以外の投 資費用に関しては，すべて金融機関から負債契約によ り調達する。さらに，自己資金から支出される保証金 に機会費用が存在すると考える。このような保証金制 度は，PFI事業の実務において幅広く用いられている。 さらに，金融機関によるモニタリングも考慮しない。

第 1 期に事業が破綻し，金融機関から追加融資を受 けないと事業を継続できない場合を考えよう。この時, 公共主体は既存 SPC との事業権契約を解除する。金融 機関が公共主体の解除権行使を受諾すれば，事業が清 算される。公共主体は金融機関に買取価格 $A$ を支払い, 事業資産を買い取る。さらに，公共主体は事業継続の ために追加費用を支出する．事業権が解除された段階 


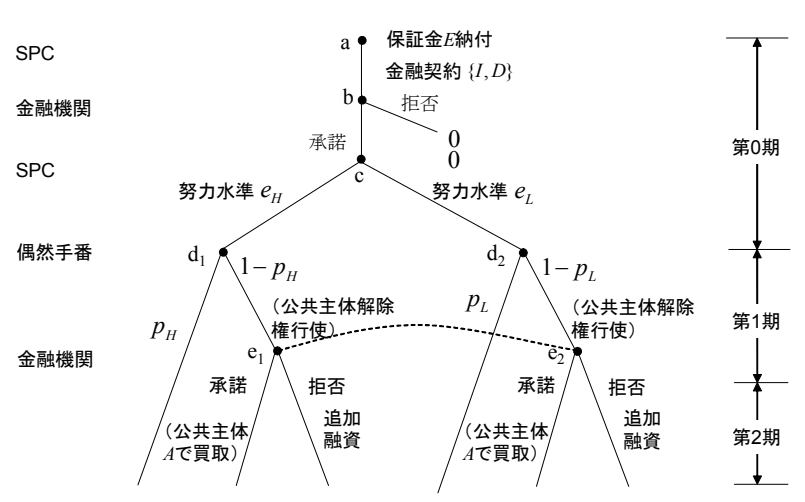

図ー3 保証金ゲーム $\Gamma_{g}$ の木

で，公共主体により保証金が没収される。公共主体は 没収した保証金を金融機関への支払いに充当する。一 方, 金融機関が公共主体による事業権解除を拒否した 場合, 金融機関は負債契約を変更し, SPCに対して追 加融資がなされる. その結果, SPCは事業を継続する ことができる。公共主体による事業権解除が実行され ず，事業が第 2 期まで継続した場合，保証金はSPCに 返還される。SPCは返還された保証金を，初期負債契 約の返済に充当することが可能である.

\section{（2）定式化と均衡解}

公共主体が保証金制度を導入したゲーム（以下，保 証金ゲーム $\Gamma_{g}$ と呼ぶ）を提案する. 図ー3は，保証金 ゲームの構造を示している. 保証金ゲームではノード $a$ において外生的に与えられたサービス対価 $R$ のとで, $\mathrm{SPC}$ が保証金 $E$ を公共主体に納める。ノード $b$ 以降は基 本ゲームГと同じ構造をもつ。事業が継続された場合, 保証金はSPCに返還される。しかし，保証金には機会 費用が発生する。すなわち, SPCが保証金として使わ れる自己資金 $E$ はほかの投資に使われる場合，第 2 期の 時点で $(1+\lambda) E(1>\lambda \geq 0)$ の利益を獲得することが できる，公共主体は保証金を運用せず，事業終了時点 まで流動性として保有する。公共主体が保証金を資本

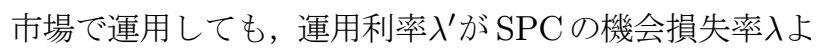
り小さい限り, 社会全体の機会損失が発生する。以下 では, 簡単のために, 公共主体が流動性として, 保証 金を保有すると仮定する。したがって，SPCが第 2 期 に保証金 $E$ を獲得しても， $\lambda E$ の損失を負うことになる. また，社会全体としても機会損失 $\lambda E$ 発生する. SPC が獲得する利潤は次式で表せる。

$$
\begin{aligned}
& \hat{\pi}_{H}^{s p c}(0)=R-D-\lambda E \\
& \hat{\pi}_{L}^{s p c}(0)=R-D+B-\lambda E \\
& \hat{\pi}_{H}^{s p c}(C)=-(1+\lambda) E \\
& \hat{\pi}_{L}^{s p c}(C)=B-(1+\lambda) E
\end{aligned}
$$

第 1 期に事業が破綻した時には，事業の継続のために追 加融資 $C$ が必要となる. 公共主体の事業権解除を金融 機関が受け入れる場合，公共主体は保証金 $E$ を没収す るとともに金融機関から買取金額 $A$ で事業を買い取る. 公共主体は改めて新しいSPC と事業権契約を締結する. 一方, 金融機関が事業権解除を拒否する場合, 新しい 負債契約が締結される。したがって, 金融機関が事業 権契約解除を受け入れる条件は

$$
A \geq R+E-C
$$

と表される。金融機関が獲得する利潤は

$$
\begin{aligned}
& \hat{\pi}_{i}^{\text {bank }}(0)=D-I(i=H, L) \\
& \hat{\pi}_{i}^{\text {bank }}(C)=\left\{\begin{array}{c}
R+E-C-I \\
(A<R+E-C \text { の時 }) \\
A-I \\
(A \geq R+E-C \text { の時 })
\end{array}\right.
\end{aligned}
$$

となる。したがって, $A<R+E-C$ 場合, 金融機 関の期待利潤 $\hat{\Pi}_{i}^{s p c}(D)(i=H, L)$ は

$$
\begin{aligned}
\hat{\Pi}_{H}^{\text {bank }}(D) & =p_{H} D \\
& +\left(1-p_{H}\right)(R+E-C)-I \\
\hat{\Pi}_{L}^{\text {bank }}(D) & =p_{L} D \\
& +\left(1-p_{L}\right)(R+E-C)-I
\end{aligned}
$$

と表せる. 一方, $A \geq R+E-C$ 場合，金融機関の 期待利潤 $\hat{\Pi}_{i}^{s p c}(D)(i=H, L)$ は

$$
\begin{aligned}
& \hat{\Pi}_{H}^{b a n k}(D)=p_{H} D+\left(1-p_{H}\right) A-I \\
& \hat{\Pi}_{L}^{b a n k}(D)=p_{L} D+\left(1-p_{L}\right) A-I
\end{aligned}
$$

となる．最後に，公共主体が負担する金額は

$$
\begin{aligned}
& \hat{\pi}_{i}^{p u b}(0)=R(i=H, L) \\
& \hat{\pi}_{i}^{p u b}(C)=\left\{\begin{array}{c}
R(A<R+E-C \text { の時 }) \\
A+C-E \\
(A \geq R+E-C \text { の時 })
\end{array}\right.
\end{aligned}
$$

となる。第 0 期に遡り， $\mathrm{SPC}$ が努力水準を選択する問 題を考えよう. 返済額 $D$ を所与として努力水準 $e_{i}(i=$ $H, L)$ を選択した場合の期待利潤 $\hat{\Pi}_{i}^{s p c}(D)(i=H, L)$ は

$$
\begin{aligned}
\hat{\Pi}_{H}^{s p c}(D)= & p_{H}(R-D) \\
& -\left(1-p_{H}+\lambda\right) E \\
\hat{\Pi}_{L}^{s p c}(D)= & p_{L}(R-D) \\
& -\left(1-p_{L}+\lambda\right) E+B
\end{aligned}
$$

となる. 社会的最適な努力水準 $e_{H}$ が選択されるための 誘因両立条件は式 (53a),(53b)より

$$
\Delta p(R-D) \geq B-\Delta p E
$$

と表される。いま, SPCが選択した努力水準 $e_{i}(i=$ $H, L)$ が既知である時, $\mathrm{SPC}$ が選択した努力水準 $e_{i}(i=$ 
$H, L)$ に対して，金融機関の期待利潤がゼロとなる臨界 的返済額 $\hat{D}_{i}(i=H, L)$ は, $A<R+E-C$ の場合,

$$
\begin{aligned}
& \hat{D}_{H}=\frac{I-\left(1-p_{H}\right)(R+E-C)}{p_{H}} \\
& \hat{D}_{L}=\frac{I-\left(1-p_{L}\right)(R+E-C)}{p_{L}}
\end{aligned}
$$

となる. 一方, $A \geq R+E-C$ の場合, 式(51a),(16b) より, 臨界的返済額 $\hat{D}_{i}^{\prime}(i=H, L)$ は,

$$
\begin{aligned}
& \hat{D}_{H}^{\prime}=\frac{I-\left(1-p_{H}\right) A}{p_{H}} \\
& \hat{D}_{L}^{\prime}=\frac{I-\left(1-p_{L}\right) A}{p_{L}}
\end{aligned}
$$

となる. 条件 $(3)$ より, $\hat{D}_{L}>\hat{D}_{H}, \hat{D}_{L}^{\prime}>\hat{D}_{H}^{\prime}$ が成立す る. その上で, $\mathrm{SPC}$ が努力水準 $e_{H}$ を選択する誘因両立 条件を考えよう.まず, $A<R+E-C$ 場合をとり あげる. 臨界的返済額 $\hat{D}_{H}$ の下で, $\mathrm{SPC}$ が努力水準 $e_{H}$ を選択する条件は

$$
\begin{aligned}
& R-\hat{D}_{H} \geq \frac{B}{\Delta p}-E \\
& p_{H}\left(R-\hat{D}_{H}\right) \geq\left(1-p_{H}+\lambda\right) E
\end{aligned}
$$

と表せる. 式(57a) は, SPCが努力水準 $e_{H}$ を選択する 誘因両立条件であり, 式 (54)より求まる. 式 (57b) は努 力水準 $e_{H}$ の実施可能条件であり, 式 $(53 \mathrm{a})$ より求まる. つぎに, 誘因両立条件 (57a) が成立しない場合を考えよ う. 努力水準 $e_{L}$ が選択されるためには

$$
\begin{aligned}
& R-\hat{D}_{H}<\frac{B}{\Delta p}-E \\
& p_{L}\left(R-\hat{D}_{L}\right) \geq\left(1-p_{L}+\lambda\right) E-B
\end{aligned}
$$

という 2 つ条件が満足されなければならない. 式 (58a) は努力水準 $e_{L}$ が選択される誘因両立条件である. 式 (58b) は努力水準 $e_{L}$ の実施可能条件である. 同様に, $A \geq R+E-C$ が成立する場合, $\operatorname{SPC}$ が努力水準 $e_{H}$ を 選択する条件は

$$
\begin{aligned}
& R-\hat{D}_{H}^{\prime} \geq \frac{B}{\Delta p}-E \\
& p_{H}\left(R-\hat{D}_{H}^{\prime}\right) \geq\left(1-p_{H}+\lambda\right) E
\end{aligned}
$$

と表せる. 努力水準 $e_{L}$ が選択される条件は

$$
\begin{aligned}
& R-\hat{D}_{H}^{\prime}<\frac{B}{\Delta p}-E \\
& p_{L}\left(R-\hat{D}_{L}^{\prime}\right) \geq\left(1-p_{L}+\lambda\right) E-B
\end{aligned}
$$

となる。

以上の結果を整理すれば，本ケースでは以下のよう

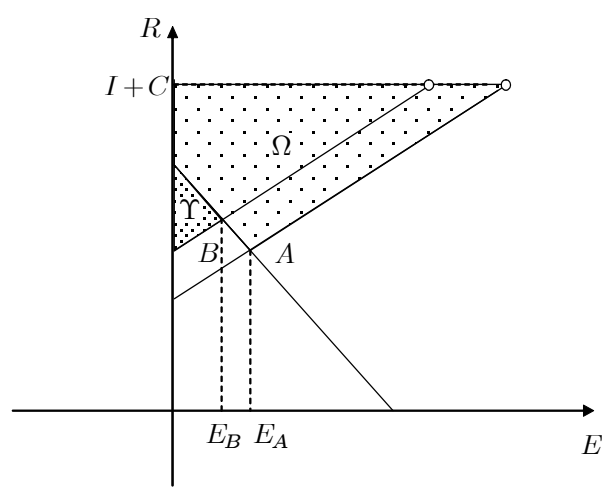

図ー4 保証金ゲームの存在条件 $(A<R+E-C$ の場合 $)$

な均衡解が存在する.

$$
\left\{\begin{array}{cl}
\text { 均衡解 } \alpha & \hat{D}^{*}=\hat{D}_{H}, \hat{e}^{*}=e_{H} \\
& (\text { 式 }(57 \mathrm{a}),(57 \mathrm{~b}) \text { が成立する時 }) \\
\text { 均衡解 } \beta & \hat{D}^{*}=\hat{D}_{L}, \hat{e}^{*}=e_{L} \\
& (\text { 式 }(58 \mathrm{a}),(58 \mathrm{~b}) \text { が成立する時 }) \\
\text { 均衡解 } \alpha^{\prime} & \hat{D}^{*}=\hat{D}_{H}^{\prime}, \hat{e}^{*}=e_{H} \\
& (\text { 式 }(59 \mathrm{a}),(59 \mathrm{~b}) \text { が成立する時 }) \\
\text { 均衡解 } \beta^{\prime} & \hat{D}^{*}=\hat{D}_{L}^{\prime}, \hat{e}^{*}=e_{L} \\
& \text { 式 }(60 \mathrm{a}),(60 \mathrm{~b}) \text { が成立する時 }
\end{array}\right.
$$

寸なわち, 均衡解 $\alpha, \alpha^{\prime}$ では, $\mathrm{SPC}$ が努力水準 $e_{H}$ を選択 し, 社会的最適な契約が実現する. 一方, 均衡解 $\beta, \beta^{\prime}$ で は, $\mathrm{SPC}$ が努力水準 $e_{L}$ を選択し, 社会的最適な契約が 実現しない.また, 均衡解 $\alpha, \beta, \alpha^{\prime}, \beta^{\prime}$ において $\mathrm{SPC}$ が獲 得する期待利潤は

$$
\begin{aligned}
& \hat{\Pi}_{\alpha}^{s p c}(E)=p_{H}\left(R-\hat{D}_{H}\right)-\left(1-p_{H}+\lambda\right) E \\
& \hat{\Pi}_{\beta}^{s p c}(E)=p_{L}\left(R-\hat{D}_{L}\right)-\left(1-p_{L}+\lambda\right) E+B \\
& \hat{\Pi}_{\alpha^{\prime}}^{s p c}(E)=p_{H}\left(R-\hat{D}_{H}^{\prime}\right)-\left(1-p_{H}+\lambda\right) E \\
& \hat{\Pi}_{\beta^{\prime}}^{s p c}(E)=p_{L}\left(R-\hat{D}_{L}^{\prime}\right)-\left(1-p_{L}+\lambda\right) E+B
\end{aligned}
$$

と表せる。また公共主体の期待支払額は

$$
\begin{aligned}
& \hat{\Pi}_{i}^{p u b}(E)=R(i=\alpha, \beta) \\
& \hat{\Pi}_{\alpha^{\prime}}^{p u b}(E)=p_{H} R+\left(1-p_{H}\right)(A+C-E) \\
& \hat{\Pi}_{\beta^{\prime}}^{p u b}(E)=p_{L} R+\left(1-p_{L}\right)(A+C-E)
\end{aligned}
$$

となる。

\section{（3）競争入札解}

まず, $A<R+E-C$ 場合を考えよう. 図一 4 は サービス対価 $R$ と保証金 $E$ 組み合わせで表現される $R-E$ 平面上で, 各均衡解が存在する領域を示してい る. 同図において, $\Omega$ は効率的な均衡解 $\alpha$ が出現する領

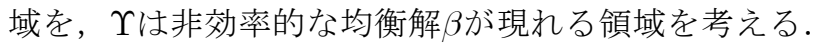
ここで，各領域の 3 つの境界

$$
R_{\bar{\alpha}}(E)=I+\left(1-p_{H}\right) C+\frac{p_{H} B}{\Delta p}-E
$$




$$
\begin{aligned}
& R_{\bar{\beta}}(E)=I+\left(1-p_{H}\right) C+\lambda E \\
& R_{\bar{\gamma}}(E)=I+\left(1-p_{L}\right) C+\lambda E-B
\end{aligned}
$$

を考える.さらに，境界 $(61 \mathrm{a})$ と $(61 \mathrm{~b})$ の交点を点 $A$, 境 界 $(61 \mathrm{a})$ と $(61 \mathrm{c})$ の交点を点 $B$ と呼ぶ.これら 2 つの交 点に対応する保証金 $E_{A}, E_{B}$ は，それぞれ

$$
\begin{aligned}
E_{A} & =\frac{p_{H} B}{\Delta p(1+\lambda)} \\
E_{B} & =\frac{\left(2 p_{H}-p_{L}\right) B-(\Delta p)^{2} C}{\Delta p(1+\lambda)}
\end{aligned}
$$

と表される.さらに，これら 2 つ保証金の間には

$$
E_{B} \leq E_{A}
$$

という関係が成立する（付録 4$)$ 参照）。ここで，公共 主体が保証金 $E$ の值を設定すると考えよう。この時，競 争入札によりサービス対価が決定される場合, 以下の 3 つの競争入札解が存在する.

$$
\left\{\begin{array}{cl}
\text { 入札解 } \bar{\alpha} & \hat{D}^{*}=\hat{D}_{H}, \hat{e}^{*}=e_{H}, \hat{R}^{*}=R_{\bar{\alpha}}(E) \\
& \left(E \geq E_{A} \text { が成立する場合 }\right) \\
\text { 入札解 } \bar{\beta} & D^{*}=\hat{D}_{H}, \hat{e}^{*}=e_{H}, \hat{R}^{*}=R_{\bar{\beta}}(E) \\
& \left(E_{B} \leq E<E_{A} \text { が成立する場合 }\right) \\
\text { 入札解 } \bar{\gamma} & \hat{D}^{*}=\hat{D}_{L}, \hat{e}^{*}=e_{L}, \hat{R}^{*}=R_{\bar{\gamma}}(E) \\
& \left(0 \leq E<E_{B} \text { が成立する場合 }\right)
\end{array}\right.
$$

ただし， $R_{\bar{\alpha}}(E), R_{\bar{\beta}}(E), R_{\bar{\gamma}}(E)$ は，それぞれ保証金 $E$ の下で競争入札により決定されるサービス対価であり， 式(61b)，(61a)，(61c)により表せる.また, 各競争入札 解において, 入札した SPC が獲得する期待利得は,

$$
\hat{\Pi}_{i}^{s p c}(E)=0(i=\bar{\alpha}, \bar{\beta}, \bar{\gamma})
$$

となる. 競争入札における均衡解金においては，モラル ハザードが発生する. $E \geq E_{B}$ を満足する保証金を前提 とした競争入札を実施することにより $\mathrm{SPC}$ のモラルハ ザードを抑制することができる，ここで，式 (61a),(61b) より, 社会的最適な入札解 $\bar{\alpha}, \bar{\beta}$ を実現するために必要と なる公共主体の期待支払額は

$$
\begin{aligned}
& \hat{\Pi}_{\bar{\alpha}}^{p u b}=I+\left(1-p_{H}\right) C+\lambda E \\
& \hat{\Pi}_{\bar{\beta}}^{p u b}=I+\left(1-p_{H}\right) C+\frac{p_{H} B}{\Delta p}-E
\end{aligned}
$$

となる. 公共主体の期待支払額 $(65 \mathrm{a})$ は領域 $\left[E_{A}, \infty\right)$ に おいて $E$ に関する増加関数であり， $E=E_{A}$ において期 待支払額は最小となる。一方, 公共主体の期待支払額 $(65 \mathrm{~b})$ は, 領域 $\left[E_{B}, E_{A}\right]$ において $E$ に関する減少関数で あり, $E=E_{A}$ において期待支払額は最小となる. 保証

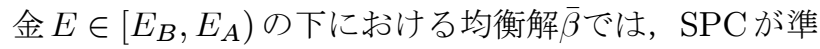
レントを獲得する。この場合，4.（4）で議論したよ うな金融機関のモラルハザードが発生する可能性があ る. 最適保証金 $E^{*}$ は

$$
E^{*}=\frac{p_{H} B}{\Delta p(1+\lambda)}
$$

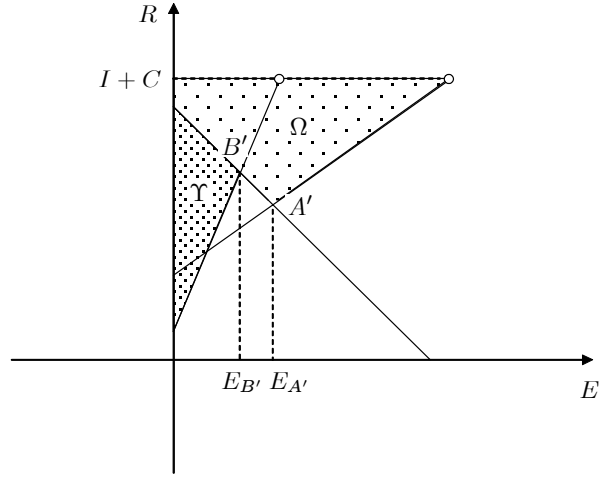

図－5 保証金ゲームの存在条件 $(A \geq R+E-C$ の場合 $)$

となる。この時，公共主体の期待支払額は

$$
\hat{\Pi}^{p u b}\left(E^{*}\right)=I+\left(1-p_{H}\right) C+\frac{\lambda p_{H} B}{\Delta p(1+\lambda)}
$$

となる。また，公共主体が事業権を解除する際に金融 機関に支払う買取価格 $A$ は

$$
A<I-p_{H} C+\frac{p_{H} B}{\Delta p}=\tau_{1}
$$

を満足する.

つぎに, $A \geq R+E-C$ が成立する場合を考えよう. 図ー 5 はサービス対価 $R$ と保証金 $E$ の組み合わせで表 現される $R-E$ 平面上で, 各均衡解が存在する領域を

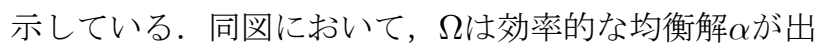
現する領域を, $は$ は非効率的な均衡解 $\beta$ が現れる領域を 表している。ここで，各領域の 3 つの境界

$$
\begin{aligned}
& R_{\bar{\alpha}^{\prime}}(E)=\frac{I-\left(1-p_{H}\right) A}{p_{H}}+\frac{B}{\Delta p}-E \\
& R_{\bar{\beta}^{\prime}}(E)=\frac{I-\left(1-p_{H}\right) A}{p_{H}}+\frac{(1-p+\lambda) E}{p_{H}} \\
& R_{\bar{\gamma}^{\prime}}(E)=\frac{I-\left(1-p_{L}\right) A}{p_{L}}+\frac{\left(1-p_{L}+\lambda\right) E}{p_{L}}-\frac{B}{p_{L}}
\end{aligned}
$$

を考える.さらに, 境界 $(69 \mathrm{a})$ と $(69 \mathrm{~b})$ の交点を点 $A^{\prime}$, 境界 $(69 \mathrm{a})$ と $(69 \mathrm{c})$ の交点を点 $B^{\prime}$ と呼ぶ. これら 2 つの 交点に対応する保証金 $E_{A}^{\prime}, E_{B}^{\prime}$ は，それぞれ

$$
\begin{aligned}
E_{A}^{\prime} & =\frac{p_{H} B}{\Delta p(1+\lambda)} \\
E_{B}^{\prime} & =\frac{\left(p_{H}\right)^{2} B-(\Delta p)^{2}(I-A)}{p_{H}(\Delta p)(1+\lambda)}
\end{aligned}
$$

と表される.さらに，これら 2 つの保証金の間には

$$
E_{B}^{\prime} \leq E_{A}^{\prime}=E_{A}
$$

という関係が成立する（付録 4）参照）。以上の結果を 
整理すれば，以下のような競争入札解が存在する.

$$
\left\{\begin{array}{cl}
\text { 均衡解 } \bar{\alpha}^{\prime} & \hat{D}^{*}=\hat{D}_{H}^{\prime}, \hat{e}^{*}=e_{H}, \hat{R}^{*}=R_{\bar{\alpha}^{\prime}}(E) \\
& \left(E \geq E_{A}^{\prime} \text { が成立する場合 }\right) \\
\text { 均衡解 } \bar{\beta}^{\prime} & \hat{D}^{*}=\hat{D}_{H}^{\prime}, \hat{e}^{*}=e_{H}, \hat{R}^{*}=R_{\bar{\beta}^{\prime}}(E) \\
& \left(E_{B}^{\prime} \leq E<E_{A}^{\prime} \text { が成立する場合 }\right) \\
\text { 均衡解 } \bar{\gamma}^{\prime} & \hat{D}^{*}=\hat{D}_{L}^{\prime}, \hat{e}^{*}=e_{L}, \hat{R}^{*}=R_{\bar{\gamma}^{\prime}}(E) \\
& \left(0 \leq E<E_{B}^{\prime} \text { が成立する場合 }\right)
\end{array}\right.
$$

ただし， $R_{\bar{\alpha}^{\prime}}(E), R_{\bar{\beta}^{\prime}}(E), R_{\bar{\gamma}^{\prime}}(E)$ は，それぞれ競争入 札解 $\bar{\alpha}^{\prime}, \bar{\beta}^{\prime}, \bar{\gamma}^{\prime}$ たおるサービス対価であり, 式 $(69 \mathrm{~b}),(69 \mathrm{a}),(69 \mathrm{c})$ により表せる。また，各競争入 札解において，入札したSPCが獲得する期待利得は，

$$
\hat{\Pi}_{i}^{s p c}(E)=0\left(i=\bar{\alpha}^{\prime}, \bar{\beta}^{\prime}, \bar{\gamma}^{\prime}\right)
$$

となる. 均衡解 $\bar{\alpha}^{\prime}, \bar{\beta}^{\prime}$ においては SPCのモラルハザード を抑止することができる．さらに，公共主体の期待支 払い額を最小にするような最適保証金額 $E^{*}$ は

$$
E^{*}=\frac{p_{H} B}{\Delta p(1+\lambda)}
$$

であり，公共主体の期待支払額は

$$
\hat{\Pi}^{p u b}\left(E^{*}\right)=I+\left(1-p_{H}\right) C+\frac{\lambda p_{H} B}{\Delta p(1+\lambda)}
$$

となる。また，公共主体が事業権を解除する際に金融 機関に支払う買取価格 $A$ は

$$
A \geq I-p_{H} C+\frac{p_{H} B}{\Delta p}=\tau_{1}
$$

を満足する. 以上の分析から, 以下の命題を得る.

命題 1 最適保証金 $E^{*}$ を用いた競争入札を実施するこ とにより，任意の買取り価格 $A \in[0, I]$ に対して，金融 機関と SPCのモラルハザードを抑止し，公共主体の期 待支払額を最小にできる.

命題 1 に示すように，保証金はSPC と金融機関のモ ラルハザードを同時に抑制するために有効な手段であ る.かつ，技術的・財務的モラルハザードの双方に有 効である。しかし，保証金額を設定するためには，モ ラルハザードによる私的便益 $B$ を計測することが必要 となる．この点が，モラルハザードと資産代替の問題 が大きくことなる点である。筆者らは前稿14)で資産代 替を抑止する保証金を標準的な施設建設費に基づいて 算定できることを指摘した。しかし，モラルハザード の場合，私的情報である私的便益 $B$ を用いて保証金の 水準を算定せざるを得ない。現実には，私的便益を計 量化することは困難であり，過去の事業経験に基づい て主観的に判断せざるを得ない。なお，保証金額が大 きくなれば，SPCが負担するリスクが大きくなる．

本研究では，リスク中立的な SPCを想定していたが, 保証金が多大になれば，リスク回避的な SPC は事業に 参加する意思を持たないだろう，SPCによる事業参加
を促進するためには，保証金額を軽減することが必要 である。また，保証金の機会費用がモラルハザードの 社会費用 $\Delta$ より大きい場合，モラルハザードをあえて 許容することが社会的望ましいといった可能性もある. したがって，モラルハザードを抑止するために，保証金 の再投資利用などによる機会費用の削減が必要である. このため，モラルハザードをすべて保証金で抑制する ことは現実的ではない。金融機関が SPCの行動をモニ タリングすることにより，SPCの財務的モラルハザー ドを抑制することができれば，保証金の水準を削減する ことができる.さらに，最適保証金の下での競争入札解 はSPCによるプロジェクトの実行可能条件 (61a),(69a) により規定されている。すなわち，金融機関はSPCの 規律づけに実質的な役割を果たしていない，金融機関 による SPCの規律づけ努力が行われば，保証金の水準 を削減することが可能となろう。以下では，金融機関 によるモニタリング行動と，モニタリングによるモラ ルハザードの抑制効果を分析する.

\section{6. モニタリングゲーム}

\section{（1）モニタリングと金融機関}

金融経済学の分野で，金融機関のモニタリング機能 を分析した研究が蓄積されている21)-27)。 その中で， Diamond $^{21)}$ は，金融機関によるモニタリング取引と非 モニタリング取引の選択問題について分析した。 モニ タリング取引とは，金融機関による借り手の行動のモ ニタリングを前提とした取引を言う。さらに，モニタ リング取引は，借り手のモラルハザードを抑える側面 （モニタリングのインセンティブ機能）と借り手を選別 する側面（モニタリングのスクリニング機能）の 2 つ の機能を有していることを指摘した. Holmstrom and Tirole ${ }^{22)}$, Tirole ${ }^{23)}$ はコーポレートガバナンスの立場か ら，金融機関のモニタリングが事業者の行動に及ぼす影 響を分析している。 一方, Gale and Hellwig ${ }^{24)}$, Krasa and Villamil ${ }^{25)}$ は不完備契約理論に基づいて，金融機関 の最適融資額の決定モデルを定式化し，モニタリング によるスクリーニング機能が事業者の資産代替を抑制 する手段となることを明らかにしている，また，Rajan and Winton ${ }^{26)}$ は，不完備契約理論に基づいて，金融機 関のモニタリングが事業破綻後における金融機関によ る事業の継続（あるいは清算）に関わる意思決定に及 ぼす影響を分析している。これら既往の研究では，金 融機関がモニタリングを実施することを前提とし，モ ニタリングが借り手の行動に及ぼす影響を分析してい る. PFI事業では，公共主体と金融機関の双方が SPC の行動の規律づけに関する役割を担うことになる．し かし，公共主体が事業の破綻リスクをすべて負担する 
ような場合，金融機関に SPC の行動をモニタリングす るインセンティブが存在しない，以下では，金融機関 がモニタリングを実施する誘因を持つような条件を明 らかにし，金融機関のモニタリングが均衡解に及ぼす 影響を分析することとする.

\section{（2）モデル化の前提条件}

これまでの分析では, 暗黙の仮定として, 金融機関が 事前審查を通じて, 負債契約のスクリーニングを実施す ることを前提としてきた．たとえば，基本モデルにおけ る効率的な均衡解 $\mathrm{A}, \mathrm{C}$ が成立するためには，1）金融 機関が誘因両立条件 (18)をモニタリングし，2）SPC がモラルハザードを引き起こすようなサービス対価を 設定する場合には, 融資契約に応じないという姿勢が必 要である.すなわち，金融機関には，モラルハザードを 前提とするような負債契約を排除するスクリーニング 機能が要請される，なお，金融機関のスクリーニング機 能とは，本来不良な借り手を選別する機能を意味する. 本研究では，金融機関が不良な負債契約であれば契約 の締結を拒否できるという意味で金融機関のスクリー ニング機能に着目していることを断っておく．金融機 関がスクリーニング機能を有するためには，金融機関 にSPCのモラルハザードを分析する能力が金融機関に 備わってなければならない，金融機関のモニタリング の役割として，SPCのモラルハザードを抑制するよう なインセンティブ機能を考えることができる. SPCの モラルハザード行動の中には, 専門的な知識や能力を 利用した技術的モラルハザードが存在する。このため, 金融機関が SPC のモラルハザードをすべて立証できる わけではない.しかし，金融機関は，財務状況のモ二 タリングを通じて, SPCの財務的モラルハザードを立 証することが可能である，本節では，金融機関が SPC の財務状況を常時観察することにより, SPCの私的便 益 $B$ （運営資金の私的流用を指す）を 0 に抑制するよう な完全モニタリングが可能であると仮定しよう，完全 モニタリングにより, SPCのモラルハザードを直接抑 制することが可能である.

第 0 期に金融機関がモニタリングの有無を選択する問 題を考えよう．金融蟣関がモニタリングする場合, SPC が努力水準 $e_{L}$ を選択しても私的便益が発生しないため, モラルハザード問題が発生しない，一方，金融機関によ るモニタリングには，モニタリング費用 $c$ が必要になる. この時, 金融蟣関がモニタリング費用を負担して, SPC の行動をモニタリングする誘因を持つか否かが問題とな る. 金融機関のモニタリング行動を $b=b_{j}(j=M, N)$ と表そう。ただし， $b_{M}$ は金融機関がモニタリングを実 施することを， $b_{N}$ はモニタリングを実施しないことを

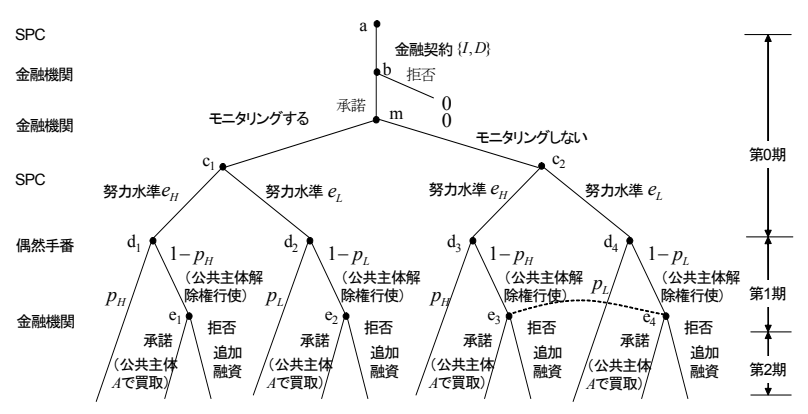

図ー 6 モニタリングゲーム $\Gamma_{m}$ の木

表す、モニタリング費用 $Z(b)$ を

$$
Z(b)= \begin{cases}c & b=b_{M} \text { の時 } \\ 0 & b=b_{N} \text { の時 }\end{cases}
$$

と表そう。金融機関がモニタリングを実施する時，初 期融資額 $I$ とモニタリング費用 $c$ を支出しなければなら

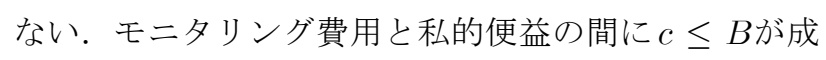
立すると仮定しょう。

\section{（3）定式化と均衡解}

第 0 期に金融機関がモニタリングの有無を決定する問 題を考えよう. 金融機関がモニタリングする場合, SPC が努力水準 $e_{L}$ を選択しても私的便益が発生しないため, モラルハザード問題が発生しない. 図一 6 は, モニタリ ングゲーム $\Gamma_{m}$ の構造を示している.ノード $a$ からノー ドbまでは基本ゲーム $\Gamma$ と同じ構造をもつ. しかし，モ ニタリングゲームでは, ノードb以降に, 以下のような 新しい部分ゲームが加わることになる.すなわち，1) 第 0 期に金融機関がモニタリングするかどうかを決定す る（ノード $m$ ）．2） SPCが努力水準を選択する（ノー ド $c_{1}$ 及び $\left.c_{2}\right)$. ついで, 第 1 期に進展し，3）偶然手番 により追加融資の有無が確定する（ノード $d_{1}, d_{2}, d_{3}$ 及 び $\left.d_{4}\right)$ ．4）第 1 期に追加融資が必要となった場合, 公 共主体は事業権契約の解除を宣言する．5）金融機関 が公共主体の事業権解除を拒否する場合, 金融機関が 追加融資を行い, 新しい負債契約が締結され第 2 期に進 む $\left(\right.$ ノード $e_{1}, e_{2}, e_{3}$ 及び $\left.\left.e_{4}\right) .6\right)$ 金融機関が公共主体 の解除権を受諾すれば事業が清算される. 公共主体は 金融機関に買取価格 $A$ を支払い, 事業資産を買い取る. (ノード $e_{1}, e_{2}, e_{3}$ 及び $\left.e_{4}\right) .7$ ) 公共主体は新しい事業 者を決定する. 8) 事業が継続した場合, 第 2 期に, 公 共主体から $\mathrm{SPC}$ にサービス対価Rが支払われる. SPC が金融機関に返済金 $D$ を支払い，事業を完了寸る.

金融機関が完全なモニタリング能力をもつことが金融 機関と SPC との間での共有情報であると考えよう．金 融機関が $b_{M}$ を選択する場合, $\mathrm{SPC}$ が努力水準 $e_{H}$ を選 
択するため, SPCが事業により獲得する利潤は

$$
\begin{aligned}
& \check{\pi}_{H}^{s p c}(0)=p_{H}(R-D) \\
& \check{\pi}_{H}^{s p c}(C)=0
\end{aligned}
$$

と表される。一方，金融機関の利潤 $\check{\pi}_{H}^{b a n k}(0), \check{\pi}_{H}^{b a n k}(C)$ は，それぞれ次式で表せる。

$$
\begin{aligned}
& \check{\pi}_{H}^{\text {bank }}(0)=D-I-c \\
& \check{\pi}_{H}^{\text {bank }}(C)=\left\{\begin{array}{c}
R-I-C-c \\
(A<R-C \text { の時 }) \\
A-I-c \\
(A \geq R-C \text { の時 })
\end{array}\right.
\end{aligned}
$$

したがって，金融機関の期待利潤 $\check{\Pi}_{H}^{b a n k}(D)$ は

$$
\check{\Pi}_{H}^{b a n k}(D)=\left\{\begin{array}{c}
p_{H} D+\left(1-p_{H}\right)(R-C)-I-c \\
(A<R-C \text { 場合 }) \\
p_{H} D+\left(1-p_{H}\right) A-I-c \\
(A \geq R-C \text { 場合 })
\end{array}\right.
$$

となる。モニタリングの実施を前提とした臨界的返済 額は, $A<R-C$ の場合, 式 (79)より

$$
D_{m}=\frac{I+c-\left(1-p_{H}\right)(R-C)}{p_{H}}
$$

となる. 一方, $A \geq R-C$ 場合, 式(79)より

$$
D_{m^{\prime}}=\frac{I+c-\left(1-p_{H}\right) A}{p_{H}}
$$

となる. 返済額 $D_{m}, D_{m^{\prime}}$ を所与とした努力水準 $e_{H}$ を選 択した場合の期待利潤 $\check{\Pi}_{H}^{s p c}\left(D_{m}\right), \check{\Pi}_{H}^{s p c}\left(D_{m^{\prime}}\right)$ は

$$
\begin{aligned}
& \check{\Pi}_{H}^{s p c}\left(D_{m}\right)=p_{H}\left(R-D_{m}\right) \\
& \check{\Pi}_{H}^{s p c}\left(D_{m^{\prime}}\right)=p_{H}\left(R-D_{m^{\prime}}\right)
\end{aligned}
$$

と表せる，金融機関がモニタリングを実施する場合，事 業の成立条件は式 $(82 \mathrm{a}),(82 \mathrm{~b})$ より

$$
\begin{array}{ll}
R \geq \nu_{m} & \left(A<\nu_{m}-C \text { の時 }\right) \\
R \geq \nu_{m}^{\prime} & \left(A \geq \nu_{m}-C \text { の時 }\right)
\end{array}
$$

と表せる。上記の条件が成立しない場合，事業自体が 成立しない（付録 5 ) 参照).ただし, $\nu_{m}=I+(1-$ $\left.p_{H}\right) C+c, \nu_{m}^{\prime}=\frac{I+c-\left(1-p_{H}\right) A}{p_{H}}$ である.したがって，本 ケースでは以下の均衡解が存在する.

$$
\begin{cases}\text { 均衡解 } M & \check{D}^{*}=D_{m}, \check{e}^{*}=e_{H}, \check{b}=b_{M} \\ & (\text { 式 }(83 \mathrm{a}) \text { が成立する時 }) \\ \text { 均衡解 } M^{\prime} & \check{D}^{*}=D_{m^{\prime}}, \check{e}^{*}=e_{H}, \check{b}=b_{M} \\ & (\text { 式 }(83 \mathrm{~b}) \text { が成立する時 })\end{cases}
$$

\section{(4) 競争入札解}

5.（3）で分析した均衡解 $M$ が成立する範囲の中で, 最小の $R$ の值を求めよう. まず, $A<\nu_{m}-C$ の場合を 考えよう。均衡解 $\mathcal{M}$ が成立するような臨界的サービス 対価 $R_{m i n}^{M}$ は

$$
R_{m i n}^{M}=\nu_{m}
$$

と表される，明らかに， $\nu_{m}<\min \left\{\nu_{1}, \nu_{2}\right\}$ が成立する （付録 5 ）参照）。したがって，金融機関が $b_{N}$ を選択 寸る場合，努力水準 $e_{H}$ が選択される誘因両立条件 (21) が成立しない。さらに, 努力水準 $e_{L}$ が選択される条件 (22) も満たされないため, 事業が成立しない. 金融市場 が完全競争であるため, 臨界的サービス対価 $\nu_{m}$ の下で, 金融機関は $b_{M}$ を選択する。したがって, $A<\nu_{m}-C$ の場合，競争入札解は

$$
\begin{cases}\text { 均衡解 } \mathcal{M} \quad \check{D}^{*}=D_{m}, \check{e}^{*}=e_{H}, \check{b}=b_{M} \\ & \check{\nu}^{*}=\nu_{m}\end{cases}
$$

となる. 競争入札解 $\mathcal{M}$ では, 金融機関がモニタリング することにより，SPCが努力水準 $e_{H}$ を選択する.

つぎに， $A \geq \nu_{m}-C$ が成立する場合を考えよう。均 衡解 $\mathcal{M}^{\prime}$ が成立するような臨界的サービス対価 $R_{m i n}^{M}$ は

$$
R_{m i n}^{M}=\nu_{m^{\prime}}
$$

と表される， $\nu_{m^{\prime}}<\min \left\{\nu_{1}, \nu_{2}, \nu_{3}\right\}$ が成立する（付録 5 ）参照）. まず, $\nu_{2}-C>A \geq \nu_{m}-C$ の場合を考 えよう. 金融機関がモニタリングしない場合, 努力水 準 $e_{H}$ が選択される誘因両立条件 $(21),(28)$ が成立しな い. さらに, $\nu_{m^{\prime}}<\nu_{2}$ が成立するため, 努力水準 $e_{L}$ が 選択される条件が満たされない。したがって, 金融機 関が $b_{M}$ を選択する．つぎに， $A \geq \nu_{2}-C$ が成立する場 合を考えよう。金融機関が $b_{N}$ を選択する場合, 努力水 準 $e_{H}$ が選択される誘因両立条件 $(21),(28)$ が成立しな い.したがって，金融機関がモニタリングする条件は

$$
\nu_{m^{\prime}}<\nu_{4}
$$

となる. 寸なわち, 努力水準 $e_{L}$ が選択される条件が成 立しないため, 金融機関は $b_{M}$ を選択する. なお, 条件 (87) が成立する必要十分条件は

$$
I-\frac{p_{L} c}{\Delta p}>A \geq \nu_{m}-C
$$

と表せる（付録 5 ）参照）。一方，

$$
I \geq A \geq I-\frac{p_{L} c}{\Delta p}
$$

が成立する場合， $\nu_{m^{\prime}} \geq \nu_{4}$ が成立する (付録 5$)$ 参 照). 均衡解 $\mathcal{M}^{\prime \prime}$ が成立するような臨界的サービス対価 $R_{m i n}^{M^{\prime \prime}}=\nu_{4}$ と表される. 競争入札価格 $\nu_{4}$ の下で, 金融 機関がモニタリングしない. したがって， $A \geq \nu_{m}-C$ の場合, 以下の競争入札解が存在する.

$$
\begin{cases}\text { 均衡解 } \mathcal{M}^{\prime} & \check{D}^{*}=D_{m^{\prime}}, \check{e}^{*}=e_{H}, \check{b}=b_{M} \\ \check{\nu}^{*}=\nu_{m^{\prime}} & (\text { 式 }(88) \text { が成立する時 }) \\ \text { 均衡解 } \mathcal{M}^{\prime \prime} & \check{D}^{*}=D_{L}^{t}, \check{e}^{*}=e_{L}, \check{b}=b_{N} \\ \check{\nu}^{*}=\nu_{4} & (\text { 式 }(89) \text { が成立する時 })\end{cases}
$$

ここに, 以下の命題が成立する.

命題 2 事業破綻時における事業の買取価格 $A$ が

$$
A \leq I-\frac{p_{L} c}{\Delta p}
$$


を満足する場合，金融機関がモニタリングを実施し， $\mathrm{SPC}$ の財務的モラルハザードを抑止する.

\section{（5）分析結果の含意}

本研究では，SPCのモラルハザードを抑制するため に, 最低価格入札, 保証金, モニタリングという $3 つ の$ 方策をとりあげた，最低価格入札制度は，モラルハザー ドにより獲得できる期待利得を上回るような準レント を SPCに与えることにより，SPCのモラルハザードを 抑制する方策である。しかし，準レントは公共主体から $\mathrm{SPC}$ 一の所得移転であり, 最低価格入札制度は財務的 効率性を達成できない，さらに，最低価格入札制度で は，金融機関が準レントの没収を図るようなモラルハ ザードが発生する．金融機関がモラルハザードを起こ せば，SPCもモラルハザードを引き起こすという悪循 環が発生する．保証金制度は，公共主体が事業権契約 を締結する段階で保証金を徵収し，最低価格入札制度 がもたらす準レントを抑止する制度である。保証金を 最適に設計することにより，最低価格入札制度下で発 生する SPC と金融機関のモラルハザードを同時に抑制 することが可能となる．さらに，金融機関が SPC の私 的便益に関する情報を持たない場合でも，技術的・財務 的モラルハザードの双方を抑制することが可能となる. この意味で，金融機関が情報を有さないような SPC に よる技術的なモラルハザードを抑制するために有効な 方策である。一方，保証金の額が大きくなれば，SPC の財務リスクが大きくなるという限界がある．保証金が 過大になると, SPCの財務リスクが大きくなり, SPC の市場参加条件を満足しなくなる危険性がある，金融 機関によるモニタリングは，SPCの私的便益を抑制す ることにより，SPCのモラルハザードの誘因に直接働 きかける方策である．特に，財務情報を通じて $\mathrm{SPC} の$ 行動が観測可能な場合，金融機関によるモニタリング が有効である．しかし，事業破綻時の買取価格が高くな ると，金融機関がモニタリングを実施する誘因を失う. 金融機関がモニタリングを実施する誘因を持つために は，金融機関にも事業破綻リスクを受け持たせること が必要となる. 本研究では, SPCのモラルハザードが 観察可能であるという前提で分析を進めてきた。しか し，現実には，金融機関がSPCによる技術的モラルハ ザード等に関して完全情報を持つことは不可能であり， 金融機関によるモニタリングにも限界が存在する，以 上より，SPCのモラルハザードを抑制するためは，金 融機関がモニタリングを実施し，財務的モラルハザー ドを可能な限り抑制することが必要である。それと同 時に，保証金によりモニタリングが困難な技術的モラ ルハザードを抑制することが必要である．保証金の水 準を抑制する上で，金融機関によるモニタリングが極
めて重要な役割を果たす。この意味で, PFI事業の効率 化を達成するために，金融機関のモニタリング技術の 向上と，金融機関自身のモラルハザードの抑制が要請 される。

\section{7. おわりに}

本研究では, PFI事業を不完備契約ゲームとして定 式化し，PFI事業における保証金とモニタリングが，モ ラルハザードを抑制する効果について分析した。具体 的には，PFI事業におけるモラルハザードを抑制する 方策として，保証金とモニタリングに着目した。保証 金制度は，技術的・財務的モラルハザードの抑制に有 効であるが，財務的効率性を担保するためには保証金 を圧縮することが望ましい。一方，モニタリングは財 務的モラルハザードの抑制に有効であるが，すべての モラルハザードを抑制できないという限界がある，以 上の観点から, 本研究では, PFI事業におけるモラルハ ザードを効率的に抑制するためには，保証金とモニタ リングの双方が必要であり，金融機関のモニタリング により財務的モラルハザードを抑制し，公共主体が徵 収する保証金の金額を縮減することが重要であること を指摘した，本研究により，以上で述べたように，PFI 事業におけるモラルハザードの発生メカニズムとその 抑制策に関する有用な知見を得ることができた。しか し, 今後に残されたいくつかの課題がある. 第 1 に, 本 研究ではモニタリングにより, 私的便益を除去するこ とが可能であることを想定した。しかし，モニタリン グにより，モラルハザードが抑制されるメカニズムに ついては分析していない．監查者と被監查者間の関係 に関しては，内部統制論 30 に対する関心の高まりを背 景として研究が進展している分野である. 今後, PFI事 業に関しても, 公共主体, 金融蟣関, SPC の内部統制 に関する研究の発展が不可欠である. 第 2 に, PFI事 業には多くのリスクが関与している．PFI事業にかか わる主体間でのリスク分担により，モラルハザードを 抑制することが可能である。このようなリスク分担メ カニズムが，事業のリスクガバナンスに及ぼす影響に 関する理論的研究が必要であろう。第 3 に, 本研究で は，事業資産の買取価格 $A$ を外生パラメータと位置づ けた．買取価格は金融機関が負担するリスクに影響を 及ぼす，その大小は負債契約におけるリスクプレミア ムに影響を及ぼすこととなる。この種の議論を行うた めにはPFI事業のクレジットリスクの計量化に関する 研究が不可欠となる. 最後に, 保証金とモニタリング の最適なポリシーミックスに関する分析が必要である. そのためには，保証金の機会費用，モニタリング費用 とその効果に関する実証的な研究の蓄積が必要である. 


\section{付録 証明および補足説明}

1) 基本ゲームの均衡解の成立条件 Case Aの場合, 臨界的返済額 $D_{H}$ に対し， $\mathrm{SPC}$ が $e_{H}$ を選択する条件は

$$
\begin{aligned}
& \Delta p\left(R-D_{H}\right)-B \geq 0 \\
& R \geq D_{H}
\end{aligned}
$$

となる. 式(91a) は, SPCが $e_{H}$ を選択するための誘因 両立条件, 式 (91b) は実施可能条件である. 式(91a)よ り, $R \geq I+\left(1-p_{H}\right) C+\frac{p_{H} B}{\Delta p}$ を得る. 一方, 式 $(91 \mathrm{~b})$ よ り, $R \geq I+\left(1-p_{H}\right) C$ を得る. $I+\left(1-p_{H}\right) C+\frac{p_{H} B}{\Delta p}>$ $I+\left(1-p_{H}\right) C$ が成立するため, 誘因両立条件 $(91 \mathrm{a})$ が 満足される時, 実施可能条件 $(91 \mathrm{~b})$ は自動的に満足され る. 仮定 $(4)$ より， $e_{H}$ が選択される条件は

$$
I+C>R \geq \nu_{1}
$$

となる.ただし， $\nu_{1}=I+\left(1-p_{H}\right) C+\frac{p_{H} B}{\Delta p}$ である. 一 方, $e_{L}$ が選択される条件は

$$
\begin{aligned}
& \nu_{1}>R \\
& R \geq \nu_{2}=I+\left(1-p_{L}\right) C \geq 0
\end{aligned}
$$

と表される. 仮定 $(2)$ より, $I+\left(1-p_{L}\right) C>C$ が成立. よって, $\operatorname{SPCが~} e_{L}$ を選択する条件は

$$
\nu_{1}>R \geq \nu_{2} \geq 0
$$

となる。ただし， $\nu_{2}=I+\left(1-p_{L}\right) C$ でる. Case B の 場合を考える. 臨界的返済額 $D_{H}^{t}$ に対して, $\operatorname{SPC}$ が $e_{H}$ を選択するための条件は

$$
\begin{aligned}
& \Delta p\left(R-D_{H}^{t}\right) \geq B \\
& R \geq D_{H}^{t}
\end{aligned}
$$

と表せる。これより， $e_{H}$ が選択される条件は

$$
I+C \geq R \geq \frac{I-\left(1-p_{H}\right) A}{p_{H}}+\frac{B}{\Delta p}=\nu_{3}
$$

と表される。一方， $e_{L}$ が選択される条件は

$$
\begin{aligned}
& \nu_{3}>R \\
& R \geq \nu_{4}=\frac{I-\left(1-p_{L}\right) A}{p_{L}} \geq 0
\end{aligned}
$$

と表される．仮定 $(5) よ り ， \frac{I-\left(1-p_{L}\right) A}{p_{L}} \geq I$ が成立する ため, $\operatorname{SPCが~} e_{L}$ を選択する条件は

$$
\nu_{3}>R \geq \nu_{4}
$$

と表される.ただし， $\nu_{4}=\frac{I-\left(1-p_{L}\right) A}{p_{L}}$ である.

2 ）競争入札解の成立条件 式 (7) を考慮すれば,

$$
\nu_{1}-\nu_{2}=\frac{p_{L} B}{\Delta p}-\Delta
$$

となる。これより，競争入札解 $\mathcal{A}$ が成立する必要十分 条件は $\Delta<\frac{p_{L} B}{\Delta p}$ かつ $A<\nu_{2}-C$ となり, 競争入札解 $\mathcal{B}$ が成立する必要十分条件は $\Delta \geq \frac{p_{L} B}{\Delta p}$ かつ $A<\nu_{1}-C$ と なる. 一方, $\nu_{3}-\nu_{4}$ は次式で表せる.

$$
\nu_{3}-\nu_{4}=\frac{B}{\Delta p}-\frac{\Delta p(I-A)}{p_{H} p_{L}}
$$

$\nu_{3}-\nu_{4}$ は $A$ の増加関数であり, $A \in\left[\max \left\{\nu_{1}, \nu_{2}\right\}-C, I\right]$ の範囲の中で, $A=I$ の時に最大, $A=\max \left\{\nu_{1}, \nu_{2}\right\}-C$ の時に最小となる. まず, $A=I$ の時に, $\nu_{3}-\nu_{4}=\frac{B}{\Delta p}>$ 0 である. つぎに, $A=\max \left\{\nu_{1}, \nu_{2}\right\}-C$ 場合を考え る. $A=\nu_{1}-C$ が成立する時, $\nu_{1}=\nu_{3} \cdot A=\nu_{2}-C$ が 成立する時, $\nu_{2}=\nu_{4}$. さらに, $\nu_{1}>\nu_{2}$ が成立する時, $A=\nu_{1}-C=I-p_{H} C+\frac{p_{H} B}{\Delta p} . \nu_{1} \leq \nu_{2}$ が成立する時, $A=\nu_{2}-C=I-p_{L} C$ である.したがって，

$$
\nu_{3}-\nu_{4}= \begin{cases}\frac{B}{\Delta p} & A=I \\ \frac{1}{p_{L}}\left(\frac{p_{L} B}{\Delta p}-\Delta\right)>0 & A=\nu_{1}-C \\ \frac{1}{p_{H}}\left(\frac{p_{L} B}{\Delta p}-\Delta\right) \leq 0 & A=\nu_{2}-C\end{cases}
$$

となる. よって, $A>\nu_{1}-C>\nu_{2}-C$ の時, $\nu_{3}>\nu_{4}$ が成立. 一方, $A>\nu_{2}-C \geq \nu_{1}-C$ の場合, 式(93)よ り $I \geq A>I-\frac{p_{H} p_{L} B}{(\Delta p)^{2}}$ が満足する時, $\nu_{3}>\nu_{4}$ が成立. 一方, $\nu_{2}-C<A \leq I-\frac{p_{H} p_{L} B}{(\Delta p)^{2}}$ となる時, $\nu_{3} \leq \nu_{4}$ が 成立. 競争入札解 $\mathcal{C}$ と $\mathcal{D}$ が成立する必要十分条件は

均衡解 $\mathcal{C}\left\{\begin{array}{l}\Delta<\frac{p_{L} B}{\Delta p} \text { かつ } A \geq \nu_{1}-C \\ \Delta \geq \frac{p_{L} B}{\Delta p} \text { かつ } A>I-\frac{p_{H} p_{L} B}{(\Delta p)^{2}}\end{array}\right.$

均衡解 $\mathcal{D} \Delta \geq \frac{p_{L} B}{\Delta p}$ かつ $I-\frac{p_{H} p_{L} B}{(\Delta p)^{2}} \geq A>\nu_{2}-C$

と表すことができる.

\section{3 ) 臨界的サービス対価の順序関係 $\quad\left(A<\nu_{1}-C\right.$ の}

場合） $A<\min \left\{\nu_{1}-C, \nu_{2}-C\right\}$ の場合を考える. $e_{H}$ に対する臨界的な返済額は $D_{H}^{*}$ となり, $e_{L}$ の臨界的返済 額は $D_{L}^{*}$ となる. $\nu_{1}>\nu_{2}=D_{L}^{*}$ が成立する必要十分条 件は付録 2 ）を参照. 返済額 $D^{\circ}=\nu_{1}$ の下で, 金融機関 が獲得する期待利潤は $p_{L} D^{\circ}+\left(1-p_{L}\right)\left(\nu_{1}-C\right)-I>$ $p_{L} D_{L}^{*}+\left(1-p_{L}\right)\left(\nu_{2}-C\right)-I=0$ を満足. つぎに, $\nu_{1}-C>A \geq \nu_{2}-C$ が成立する場合を考える. $e_{H}$ に対する臨界的な返済額は $\nu_{1}, e_{L}$ の臨界的な返済額は $D_{L}^{t}=\nu_{4}$ となる. さらに, $\nu_{1}>\nu_{2} \geq \nu_{4}$ が成立. 返 済額 $D^{\circ}=\nu_{1}$ の下で, 金融機関が獲得する期待利潤は $p_{L} D^{\circ \circ}+\left(1-p_{L}\right) A-I>p_{L} D_{L}^{t}+\left(1-p_{L}\right) A-I=0$ を満 足する. ( $A \geq \nu_{1}-C$ の場合 $) \quad$ まず, $A \geq \max \left\{\nu_{1}-\right.$ $\left.C, \nu_{2}-C\right\}$ の場合を考える. $e_{H}$ が選択される臨界的な 返済額は $D_{H}^{t}, e_{L}$ の臨界的な返済額は $D_{L}^{t}=\nu_{4} \cdot \nu_{3}>$ $\nu_{4}=D_{L}^{t}$ が成立する必要十分条件は付録 2 ）を参照. 返 済額 $D^{\circ \circ}=\nu_{3}$ の下で，金融機関が獲得する期待利潤は $p_{L} D^{\circ \circ}+\left(1-p_{L}\right) A-I>p_{L} D_{L}^{t}+\left(1-p_{L}\right) A-I=0$ を 満足する. つぎに, $\nu_{2}-C>A \geq \nu_{1}-C$ が成立する場 合を考える. $e_{H}$ に対する臨界的な返済額は $D_{H}^{t}, e_{L}$ に 対して $D_{L}^{*}=\nu_{2}$ となる. さらに， $\nu_{2}>\nu_{1} \geq \nu_{3}$ が成立.

4) $E_{A} \geq E_{B}, E_{A^{\prime}} \geq E_{B^{\prime}}$ の証明 $E_{A}-E_{B}=$ $\frac{\Delta p C-B}{1+\lambda} \geq 0$. 仮定 (7)より, $\Delta p C-B \geq 0$ となり, $E_{A} \geq E_{B}$ が成立. $E_{A^{\prime}}-E_{B^{\prime}}=\frac{\Delta p(I-A)}{p_{H}(1+\lambda)} \geq 0$. 仮定 (5)より, $I \geq A$ となり, $E_{A^{\prime}} \geq E_{B^{\prime}}$ が成立.

$5)$ モニタリングゲームの競争入札解の成立条件 $\quad(A<$ $\nu_{m}-C$ の場合) $\nu_{1}-\nu_{m}=\frac{p_{H} B}{\Delta p}-c>B-c>0$ となる. 
$\nu_{2}-\nu_{m}=\Delta p C-c \geq B-c>0$ となる.したがって， $\nu_{m}<\min \left\{\nu_{1}, \nu_{2}\right\}$ が成立. 明らかに, $A<\nu_{m}-C<$ $\min \left\{\nu_{1}-C, \nu_{2}-C\right\}$ が成立. $\left(A \geq \nu_{m}-C\right.$ の場合 $)$ $\nu_{m}-\nu_{m^{\prime}}=\frac{\left(1-p_{H}\right)\left(A-I+p_{H} C-c\right)}{p_{H}}$ となり, $A \geq \nu_{m}-C$ は $A \geq I-p_{H} C+c$ と同值であり, $\nu_{m}-\nu_{m^{\prime}}>0$. した がって, $\nu_{m^{\prime}}<\nu_{m}<\min \left\{\nu_{1}, \nu_{2}\right\}$ が成立. $\nu_{3}-\nu_{m^{\prime}}=$ $\frac{1}{p_{H}}\left(\frac{p_{H} B}{\Delta p}-c\right)>0$ となり, $\nu_{m^{\prime}}<\nu_{3}$ が成立. $A \geq \nu_{2}-C$ は $A \geq I-p_{L} C$ と同值. $\nu_{4}-\nu_{m^{\prime}}=\frac{\Delta p(I-A)}{p_{H} p_{L}}-\frac{c}{p_{H}}$ より, $\nu_{4}>\nu_{m^{\prime}}$ は $A<I-\frac{p_{L} c}{\Delta p}$ と同值. いま, $I-\frac{p_{L} c}{\Delta p}-(I-$ $\left.p_{L} C\right)=\frac{p_{L}(\Delta p C-c)}{\Delta p}>0$ が成立するため, $I-\frac{p_{L} c}{\Delta p}>A \geq$ $\nu_{2}-C$ を満足する $A$ が存在する. 一方, $I \geq A \geq I-\frac{p_{L} c}{\Delta p}$ が成立する時, $\nu_{m^{\prime}} \geq \nu_{4}$ が成立.

\section{参考文献}

1) 伊藤秀史: 契約の経済理論, 有斐閣, 2003 .

2) Laffont, J. and Martimort, D.: The Theory of Incentives, Princeton University Press, 2002.

3) 柳川範之: 契約と組織の経済学, 東洋経済新報社, 2000 .

4) Hart, O.: Firms Contracts and Financial Structure, Oxford University Press, 1995.

5) Myers, S.: The determinants of corporate borrowing, Journal of Financial Economics, Vol.5, pp.147-175, 1977.

6) Jensen, M. and Meckling, J.: Theory of the firm: Managerial behavior, agency costs, and capital structure, Journal of Financial Economics, Vol.3, pp.305360, 1976.

7) Detragiache, E.: Public versus private borrowing: A theory with implication for bankruptcy reform, Journal of Financial Intermediation, Vol.3, pp.327-354, 1994.

8) Hart, O., Shleifer, A. and Vishny, W. : The proper scope of government: theory and an implication to prisons, Quartely Journal of Economics, Vol.112, pp.1127-1161, 1997.

9) Bennett, J. and Iossa, E.: Building and Managing Facilities for Public Services, Discussion Paper, Department of Economics and Finance, Brunel University, 2004.

10) Bennett, J. and Iossa, E.: Public-Private Parnership: An Incomplete Contract Approach, Research Report, Department of Economics and Finance, Brunel University, 2005.

11) 大島考介: 不完備契約とPFI, 日本経済研究, No.43, pp.87-100, 2001.

12) 三井清 : PFI と内部情報一中途解約と負債による規律づ け, ESRI Discussion Paper Series, No.28, 内閣府経 済社会総合研究所, 2003 .
13) 大西正光，石磊，小林潔司：インフラPFIにおける契約 保証金と補助金の役割, 建設マネジメント研究論文集, Vol.12. pp.149-158, 2005.

14) 石䂞, 大西正光, 小林潔司 : PFI事業権契約の効率性と 保証金，土木学会論文集 D, Vol.62, No.3, pp.383-400, 2006.

15) Schmidt, K.M. : The costs and benefits of privatization: an incomplete contracts approach, Journal of Law, Economics and Organization, Vol.12, pp.1-24, 1996.

16) Schmidt, K.M. : Incomplete contract and privatization, European Economic Review, Vol.40, pp.569-579, 1996.

17) Kornai, J., Maskin, E. and Roland, G.:Understanding the soft budget constraint, Journal of Economic Literature, Vol.41, No.4, pp.1095-1136, 2003.

18) Aghion, P. and Bolton, P.: An incomplete contracts approach to financial contracting, The Review of Economic Studies, Vol.59, pp.473-494, 1992.

19) Hart, O. and Moore, J.: Default and renegotiation: A dynamic model of debt, Quartely Journal of Economics, Vol.113, pp.1-41, 1994.

20) 岡田章: ゲーム理論, 有斐閣, 1996.

21) Diamond, D.W.: Financial intermediation and delegated monitoring, Review of Economic Studies, Vol.56, pp.393-414, 1984.

22) Holmstrom, B. and Tirole, J.: Financial intermediation, loanable funds, and the real sector, The Quarterly Journal of Economics, Vol.112, pp.663-691, 1997.

23) Tirole, J.: Corporate governance, Econometrica, Vol.69, pp.1-35, 2001.

24) Gale, D. and Hellwig, M.: Incentive-compatible debt contract: The one-period problem, The Review of Economic Studies, Vol.52, pp.647-663, 1985.

25) Krasa, S. and Villamil, A.: Optimal contracts when enforcement is a decision variable, Econometrica, Vol.68, pp.119-134, 2000.

26) Rajan, R. and Winton, A.: Covenants and collateral as incentive to monitor, The Journal of Finance, Vol.50, pp.1113-1146, 1995.

27) Dessi, R.: Start-up finance, monitoring, and collusion, Rand Journal of Economics, Vol.36, pp.255-274, 2005.

28) Klemperer, P.: Auctions: Theory and Practice, Prineton University Press, 2003.

29) Milgrom, P.: Putting Auction Theory to Work, Cambridge University Press, 2004.

30) 加藤達彦: 監査制度デザイン論, 森山書店, 2005 .

(2006. 4. 27 受付)

\section{MORAL HAZARD IN PFI PROJECTS}

\section{Lei SHI, Masamitsu OHNISHI and Kiyoshi KOBAYASHI}

This paper examines the roles of guarantees and monitoring systems to conquer moral hazard issues in PFI (Private Financial Initiative) projects. The moral hazard is classified into two types: technological and financial ones. The guarantees can deter moral hazard, but generates financial inefficiency caused by opportunity costs. The monitoring systems are valid for the deterrence of the financial moral hazard. The paper concludes the combination of the guarantee and monitoring systems end up with the efficient means to resolve the moral hazard issues, as far as the monitoring costs are sufficiently low. 